\title{
Q $N_{52}^{11}$ no. 152 \\ Department Bulletin
}

Published fortnightly by the University of the State of New York

Entered as second-class matter June 24, r 908 , at the Post Office at Albany, N. Y., under the act of July $I 6,1894$

\author{
No. 504 \\ ALBANY, N. Y.

\section{New York State Museum} \\ John M. Clarke, Director \\ Museum Bulletin ${ }^{52}$ \\ YEOLOGY OF THE HONEOYE-WAYLAND \\ QUADRANGLES \\ : \\ BY \\ D. DANA LUTHER
}

OCTOBER I, I9I I

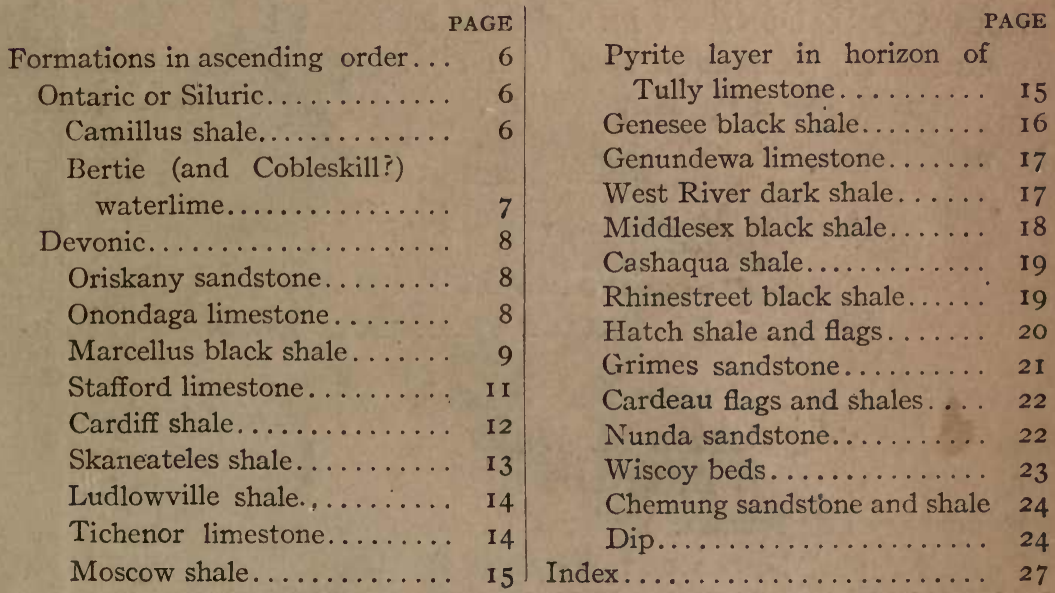

ALBANY

UNIVERSITY OF THE STATE OF NEW YORK

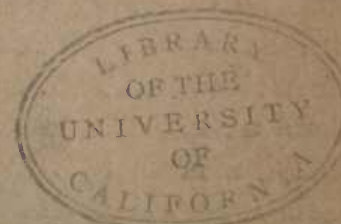

I9I I 


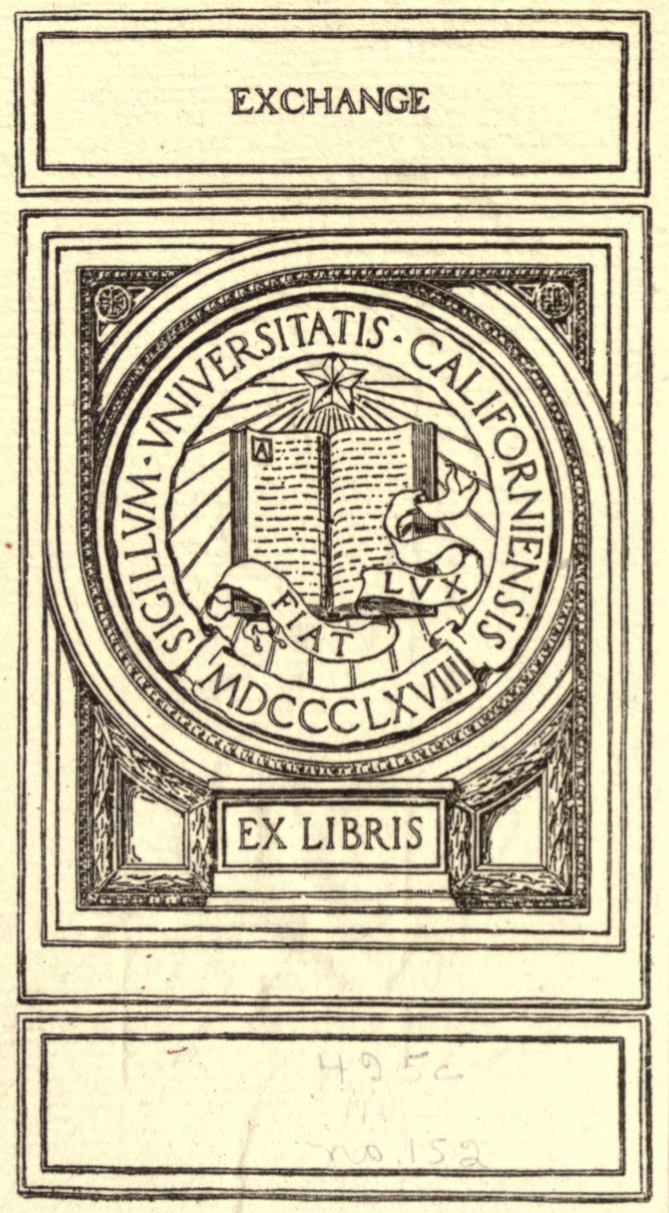






\section{New York State Education Department}

\section{Science Division, December 2, I9IO}

Hon. Andrew S. Draper LL.D.

\section{Commissioner of Education}

SIR: I have the honor to transmit to you herewith and to recommend for publication as a bulletin of the State Museum a manuscript report and map covering the geology of the Honeoye and Wayland quadrangles of the geological map of the State, which have been prepared by Mr D. Dana Luther, of this staff.

Very respectfully

$$
\text { John M. Clarke }
$$

Director

STATE OF NEW YORK

EDUCATION DEPARTMENT

COMMISSIONER'S ROOM

Approved for publication this $2 d$ day of December IOIO

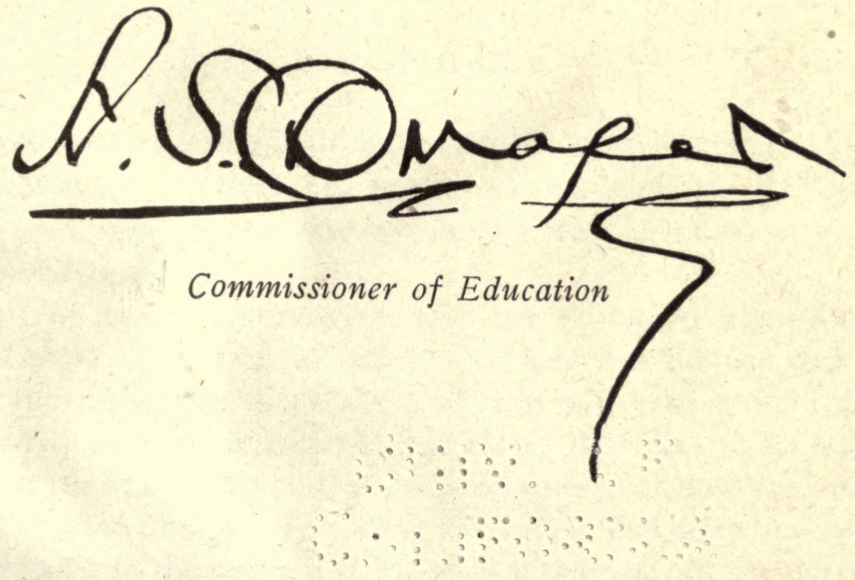


211
$N 52$

mo. 152 


\section{Education Department Bulletin}

Published fortnightly by the University of the State of New York

Entered as second-class matter June 24, r908, at the Post Uffice at Albany, N. Y., under the act of Congress of July 16,1894

No. $5 \circ 4$

ALBANY, N. Y.

OCTOBER I, IgI I

\section{New York State Museum}

John M. Clarke, Director

Museum Bulletin I52

GEOLOGY OF THE HONEOYE-WAYLAND QUADRANGLES

By D. Dana Luther

The Honeoye-Wayland quadrangles are included between the lines of latitude $42^{\circ} \cdot 30^{\prime}$ and $43^{\circ}$ north, and of longitude $77^{\circ} 30^{\prime}$ and $77^{\circ} 45^{\prime}$ west and contain one-eighth of a degree, or about $44 \mathrm{I}$ square miles of territory.

The rocks of these quadrangles have an estimated aggregate thickness of about 2660 feet, of which I $_{5}$ Io feet are surface rocks because of the difference in altitude between the lowest outcrop, which is on Honeoye creek near Sibleyville at 590 feet A. T., and the highest, at the top of Sand hill near the south line of the Wayland quadrangle at 2100 feet A. T. Eleven hundred and fifty feet of strata are brought to the surface by their elevation toward the north at an average rate of about 33 feet per mile.

These rocks embrace the following geological subdivisions or formations, twenty-four in number, which are represented by distinctive colors on the accompanying map. 


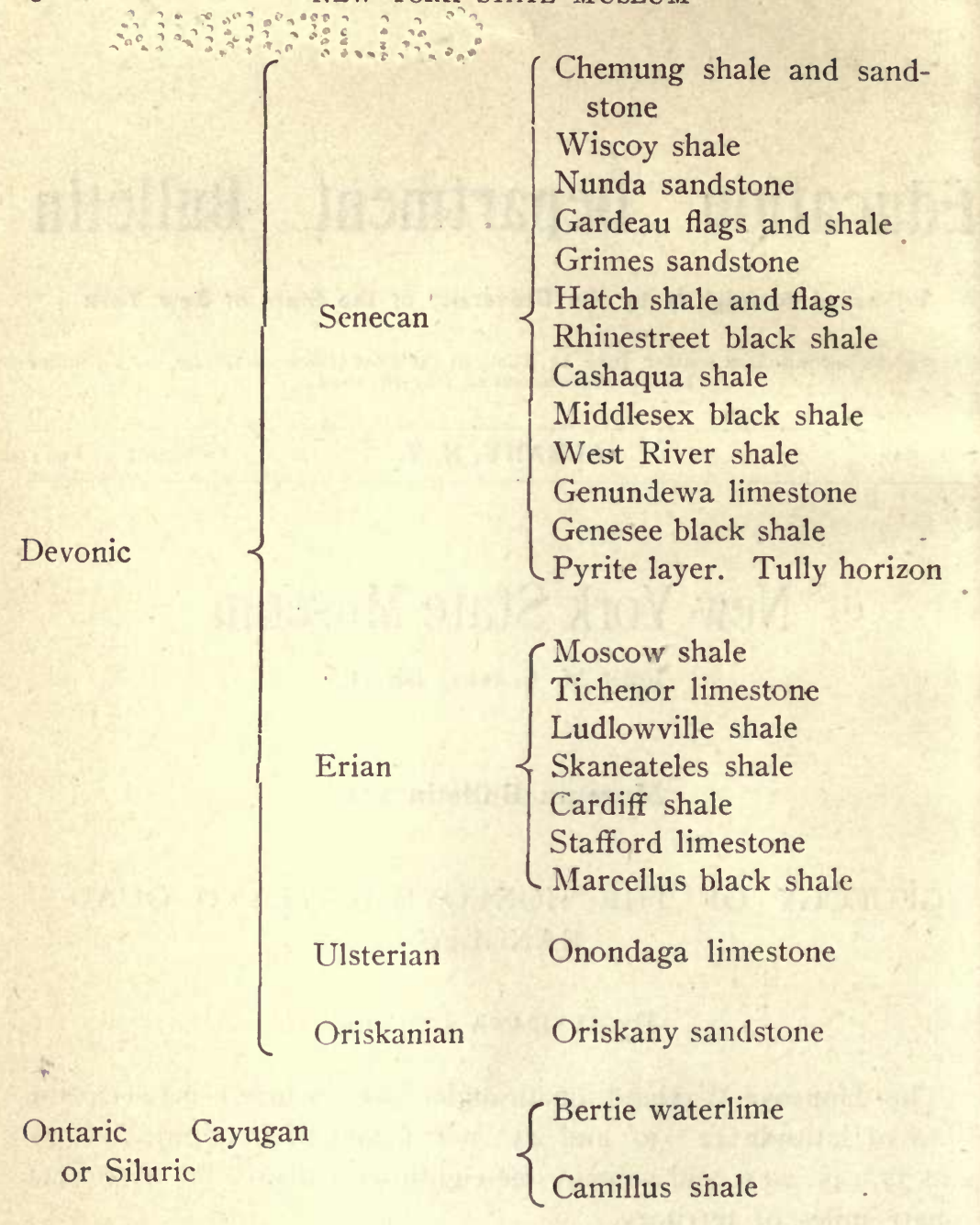

\section{FORMATIONS IN ASCENDING ORDER ONTARIC OR SILURIC \\ CAMILLUS SHALE}

The drift hills on the northern border of the Honeoye quadrangle rest upon thin magnesian limestones and soft gypseous shales belonging to this formation, which receives its name from the town of Camillus, Onondaga county, where the first discovery of gypsum in the United States was made in the year 1792, and where the beds of this formation are abundantly exposed. 
The Camillus strata are entirely covered on these quadrangles, but are exposed at Victor on the Canandaigua quadrangle and at Wheatland and Garbuttsville on the B̈rockport quadrangle.

$-$

\section{BERTIE (AND COBLESKILL?) WATERLIME}

The Camillus shales are succeeded by 85 to ioo feet of waterlimes varying in character from hard, flaggy layers to beds of soft dolomite in which lines of deposition are very obscure. At the top of this formation, in the vicinity of Honeoye Falls, there are exposed 35 feet of waterlime, of which 3 feet 6 inches at the top are in uneven layers 2 to 6 inches thick and break easily into small rough blocks. It is quite probable that this stratum, which somewhat resembles the "bullhead" of Erie county, should be correlated as Cobleskill waterlime, but no fossils are found in it.

Next below these are 20 feet of hard waterlimes showing faint lines of bedding. Some parts have no regular fracture. In this vicinity, this bed has been quarried quite largely for building purposes.

The underlying ten feet of rock are flaggy and at one or two horizons quite shaly. The lower beds are generally softer, and in some parts shaly, but there are thin hard layers separated by thin partings of black bituminous matter and heavier strata of softer waterlimes that have no regular fracture. The contact with the Camillus shales is not exposed on this quadrangle.

The waterlimes are exposed along the Hemlock outlet in the village of Honeoye Falls below the milldam east of the high school building, and along the stream to below the Lehigh Valley Railroad bridge. There are quarries in the upper beds east and west of the south end of this bridge, where the contact with the Oriskany horizon also appears. There are good exposures of forty feet of the upper beds along Spring creek two miles west of Honeoye Falls, and in the large old quarry one-fourth of a mile south of the New York Central Railroad bridge over this stream.

There is a small exposure of waterlime near an old limekiln one and one-half miles west of Spring creek with the Onondaga limestone five feet higher, and small outcrops of this rock occur in the bed of Stony brook at Five Corners.

In the central part of the State and in Erie county the waterlime beds contain fossils of several species, but the strata exposed on this quadrangle are almost barren. Le perditia a $1 \mathrm{ta}$ (Con$\mathrm{rad}$ ) and Whitfieldella la evis (Whitfield) are the only forms observed. 
In the salt shaft near Livonia on the Honeoye quadrangle the following fossils were found in these beds:

Spirifer vanuxemi $\mathrm{Hall}$

Stropheodonta varistriata (Conrad)

Liopteria rugosa Hall

Leperditia alta (Conrad) and a small Favosites

\section{DEVONIC}

ORISKANY SANDSTONE

This formation is represented here by eight inches of gray calcareous sandstone containing no fossils. It is exposed in the rock wall along Hemlock outlet at the dam east of the high school at 634 A. T. in Honeoye Falls and also at the south end of the Lehigh Valley Railroad bridge one-half mile northwest of the village. In the Livonia salt shaft there were at this horizon five feet of coarse, green and gray conglomerate containing eight species of brachiopods, suggestive of a commingling of the faunas of the Oriskany sandstone and Schoharie grit of the eastern part of the State. They are

Pentamerella $c f$. arata (Conrad)

Atrypa reticularis (Linné)

Orthis $c f$. propinqua (Hall)

Hipparionyx proximus Vanuxem

Stropheodonta $s p$.

Pentagonia unisulcata (Conrad)

Spirifer $c f$. arenosus Conrad

ONONDAGA LIMESTONE.

The Onondaga limestone is composed of layers or tiers of blue gray limestone, separated by partings of dark shale or black bituminous matter.

Dark chert or impure flint in nodules or nodular layers is unevenly distributed throughout nearly the entire formation, but is in larger proportion in the lower part, except for an uneven stratum two to five feet thick at the base, which is largely composed of corals and from which chert is absent.

The cherty lower beds supply the material for the crushed stone used in roadmaking and for ballast, while the basal stratum and the layers clear from chert found in the upper part of the formation furnish an inexhaustible supply of valuable building stone and quicklime. 
The entire section of this formation is exposed along Honeoye creek from the Monroe milldam in Honeoye Falls to the north side of the bend half a mile south of North Bloomfield, except for a small hiatus in the middle of the formation between the two villages. The lower beds may be seen along the bed of Spring creek and the upper tiers in the quarry of the Genesee Lime Company two miles southwest of Honeoye Falls. The basal layer, specially rich in corals, outcrops over an area of half an acre near an old limekiln three miles west of Honeoye Falls near a north and south road one and one-eighth miles west of Spring creek. Some of the lower tiers outcrop in the road south of Five Corners, and there are several field outcrops farther south in the region drained by Stony brook.

The fauna of the Onondaga limestone is very large; a list of species found in this formation, given in State Museum Bulletin 63, contains 3 fishes, 39 crustaceans, I 3 cephalopods, 3 pteropods; 38 gastropods, I 5 lamellibranchs, 48 brachiopods, 4 crinoids and 30 corals; total i93.

\section{MARCELLUS BLACK SHALE}

The blue Onondaga limestone is succeeded by black, carbonaceous shales and soft, dark impure limestones to the thickness of $4 \mathrm{I}$ feet in the Livonia salt shaft but somewhat thinner on the line of outcrop. On these quadrangles this shale is terminated at the top by the Stafford limestone, and it constitutes the lower division of the "Marcellus shale," as described by Hall and Vanuxem.

The lower beds are mostly calcareous and fossiliferous, while the upper are composed mainly of densely black bituminous and pyritiferous shale in which occur spherical concretions six inches to one foot, six inches in diameter.

This formation is rich in hydrocarbons and is the source of the natural gas produced by the shallower gas wells of this region. Many of the concretions are septaria and the cavities within them occasionally contain. a small quantity of petroleum. On account of the compact character of this rock, gas wells terminating in it are not very productive except when a crevice or large pocket is penetrated. Fossils are abundant, specially in the lower more calcareous part on this formation.

The following species were found in the Marcellus shale and limestone in the Livonia salt shaft, in the upper black shale and concretions : 
Plates of Aspidicthys and Dinichthys halmodeus (Clarke)

Orthoceras nuntium Hall

O. subulatum Hall .

Tornoceras uniangulare (Conrad)

Cyrtoceras citum Hall

Pleurotomaria rugulata $\mathrm{Hall}$

Styliolina fissurella Hall

Panenka lincklaeni Hall

P. equilatera Hall

Nuculites nyssa Hall

Pterochaenia fragilis (Hall)

Liopteria laevis Hall

Pterinopecten dignatus $\mathrm{Hall}$

Actinopteria muricata Hall

Orbiculoidea minuta Hall

Liorhynchus limitare (Vanuxem)

Chonetes mucronatus Hall

The following additional species occur in the more calcareous beds near the base of the formation:

Phacops rana Green

Orthoceras incarceratum Clarke

O. lima Hall

Tentaculites gracilistriatus Hall

Pleurotomaria lucina Hall

Aviculopecten $c f$. fasciculatus Hall

Modiomorpha subalata (Conrad)

M. concentrica Hall

Cypricardinia indenta (Conrad)

Microdon bellistriatus (Conrad)

Nuculites oblongatus Conrad

Palaeoneilo plana (Conrad)

Tropidoleptus carinatus (Conrad)

Spirifer audaculus Conrad

Ambocoelia umbonata (Conrad)

A. praeumbona Hall

Athyris spiriferoides (Eaton)

Coelospira camilla Hall

Terebratula $s p$.

Stropheodonta inequistriata (Conrad)

Leptostrophia perplana (Conrad) 
Orthothetes pandora Hall

O. bellulus Clarke

Orthis $c f$. lenticularis Hall

Chonetes deflectus Hall

C. lineatus (Conrad)

C. $c f$. yandellanus Hall

Pholidops hamiltoniae Hall

Stictopora incisurata Hall

Stereolasma rectum Hall

The Marcellus beds are covered on this quadrangle except for a small exposure under the Erie Railroad bridge over Little Conesus creek a mile south of Avon.

\section{STAFFORD LIMESTONE}

This formation takes its name from Stafford, Genesee county, where it is well exposed. It is eight feet three inches thick at Lancaster, Erie county, but diminishes gradually toward the east, and at its extreme eastern exposure on Flint creek, Ontario county, is but four inches thick.

On this quadrangle it is a hard blue limestone, in one stratum I 4 to 18 inches thick with a few inches of calcareous shale above and below.

There are no exposures of the Stafford limestone on these quadrangles but it may be seen below the second dam on Conesus outlet west of Ashantee, and in the bed of Little Conesus creek east of the Erie Railroad bridge.

The Stafford limestone is rich in fossils at every exposure and a list published in State Museum Bulletin 49 contains the names of I 8 species which have been collected from it. This stratum occurs in the Livonia salt shaft at the depth of 823 feet and contained the following forms:

Phacops rana Green

Orthoceras aedipus Hall

O. $c f$. marcellense Hall

Loxonema delphicola Hall

Pleurotomaria sulcomarginata (Conrad)

P. itys Hall

P. lucina Hall

Meristella barrisi Hall 

Camarotoechia sappho Hall
C. horsfordi Hall
Chonetes scitulus Hall
C. mucronatus Hall
Strophalosia truncata Hall
Ambocoelia umbonata (Conrad)
Orthothetes arctostriatus Hall
Spirifer subumbona Hall
S. audaculus (Conrad)
Atrypa recticularis Linné
Panenka lincklaeni Hall
P. aequilatera Hall
Pterinopecten exfoliatus Hall
Actinopteria muricata Hall
Aviculopecten bellus Conrad
Styliolina fissurella Hall

\section{CARDIFF SHALE}

The shales succeeding the Stafford limestone and formerly known as upper Marcellus, are richly bituminous, though in a somewhat less degree than those below, for about sixty feet gradually becoming more argillaceous and lighter colored, and passing into the next higher formation.

The only exposure of the Cardiff shale on this quadrangle is along Little Conesus creek between the Erie Railroad bridge and the Avon reservoir. In the Livonia shaft section these beds were penetrated at 753 to 823 feet and the following species were found in them:

Tornoceras uniangulare (Conrad)

Orthoceras subulatum Hall

O. nuntium Hall

Cyrtoceras $s p$.

Pleurotomaria rugulata Hall

P. capillaria (Conrad)

Bellerophon leda Hall

Liopteria laevis Hall

Modiella pygmaea (Conrad)

Pterochaenia fragilis (Hall)

Actinopteria muricata Hall

Buchiola retrostriata $v$. Buch

Actinopteria (small) $s p$.

Panenka lincklaeni Hall 
Pterinopecten dignatus Hall

Nuculites triqueter Conrad

Modiomorpha $c f$. subalata (Conrad) *

Liorhynchus limitare Vanuxem

Productella spinulicosta Hall

Strophalosia truncata Hall

Orbiculoidea minuta Hall

Styliolina fissurella Hall

Reptaria stolonifera Rolle

SKANEATELES SHALE

This formation is a bed of soft dark clayey shales quite bituminous and pyritiferous in some parts and containing fossils but sparingly, though a few thin calcareous lentils are composed almost entirely of compressed shells.

It is 145 feet thick and is terminated at the top by a stratum of hard calcareous sandy shale containing cyathophylloid corals in abundance.

Skaneateles shale is exposed along Little Conesus creek below the Avon reservoir, but is not seen elsewhere on these quadrangles.

Its place in the Livonia shaft section is 608 to 753 feet below the top.

The following fossils occur in these beds:

Phacops rana Green

Cryphaeus boothi Green

Tornoceras uniangulare (Conrad)

Orthoceras exile Hall.

Gomphoceras $s p$.

Pleurotomaria rugulata Hall

Bellerophon leda Hall

Pterochaenia fragile ( $\mathrm{Hall}$ )

Liopteria laevis Hall

Panenka equilatera Hall

Palaeoneilo fecunda Hall

Orthonota undulata Conrad

Chonetes scitulus Hall

C. lepidus Hall

C. mucronatus Hall

Liorhynchus multicostum Hall

L. limitare (Vanuxem)

Styliolina fissurella Hall

Crinoid stems 


\section{LUDLOWVILLE SHALE}

This formation consists of beds of shale varying in character from black and bituminous to light colored sandy and calcareous. Calcareous concretions are quite common, and 65 feet above the base and near the top there are even layers of limestone one to two feet thick.

The Ludlowville shale is terminated at the top by the Tichenor limestone.

The basal hard layer, which is a coral reef at Centerfield, Ontario county, and a calcareous sandstone in the Livonia shaft section, is exposed at an old mill site on Little Conesus creek near the Avon reservoir, but is almost entirely devoid of fossils.

Along Gates creek two miles north of Allens Hill 15 to 20 feet of the shales next below the Tichenor limestone are exposed.

This formation was named from its exposure along the shore of Cayuga lake near Ludlowville, Tompkins county. It extends across central and western New York and is everywhere richly fossiliferous. Lists of the fossils composing its fauna may be found in volume I of the Report of the State Geologist for I893 and in State Museum Bulletin 63 .

\section{TICHENOR LIMESTONE}

A stratum of limestone about one foot in thickness overlies the Ludlowville shale from Cayuga county to Lake Erie. It was known by the geologists of the early State Survey as the Encrinal limestone and serves as a bench mark in the stratigraphy of the western part of the State. The name Encrinal limestone was applied to the stratum on account of the abundance of crinoid fragments which it contains and of which it is, at some localities, almost entirely composed.

A calcareous stratum of somewhat similar appearance to the Tichenor limestone which occurs at the base of the Ludlowville shale and outcrops at Centerfield on the Canandaigua quadrangle, on the Attica quadrangle and other places in western New York, has sometimes been erroneously identified as the Encrinal, hence a more specific name has proved desirable. The favorable exposure in Tichenor gully on the west shore of Canandaigua lake suggested the present name. A small exposure on Gates creek near the old milldam is the only one on these quadrangles where Tichenor appears. The following is a partial list of the fossils that occur in it:

Phacops rana Green

Orthoceras caelamen Hall 
Diaphorostoma lineatum (Conrad)

Lyriopecten orbiculatus Hall

Spirifer mucronatus Conrad

Sp. granulosus (Conrad)

Heliophyllum halli Edwards \& Haime

Favosites argus Hall

F. arbusculus Hall

Eridophyllum $s p$.

Heads of Megistocrinus and other crinoids are sometimes found in the soft shale that immediately overlies the limestone.

\section{MOSCOW SHALE}

Succeeding the Tichenor limestones there are 147 feet of shale, in which calcareous concretions and thin calcareous lenses, composed largely of crinoid and other fossils, are common. The principal part of the shale is light bluish gray and quite calcareous, but at some horizons it is quite dark. Iron pyrite in nodules is commion, specially in the upper beds and occasionally occurs in the shape of casts of small fossils.

East of Canandaigua lake the upper limit of this formation is the base of the Tully limestone which does not extend west of the town of Gorham, Ontario county, but in its place there is found at some exposures a thin layer of iron pyrite separating the blue Moscow shale from the black Genesee.

The upper part of the Moscow shale, with overlying pyrite layer and Genesee shale, is exposed along Hemlock creek south of Richmond Mills, and the base of the formation on Gates creek (sometimes called Beebe brook). Its place in the Livonia shaft section is 280 to 427 feet from the top.

This formation is very rich in fossils. For lists of species see I3th Report of the State Geologist, volume I, I893, and State Museum Bulletin 63 .

\section{PYRITE LAYER. HORIZON OF TULLY LIMESTONE}

The formation of hard limestone, named from its best development at Tully, Onondaga county, where it has a thickness of 28 feet, thins out toward the west and disappears on the east side of Canandaigua lake. Westward across the Canandaigua and Honeoye quadrangles lentils of iron pyrites from one to four inches thick and 
two to ten rods across, occur in the horizon of the Tully limestone so frequently as to appear at nearly every exposure of the MoscowGenesee contact. When freshly exposed the stratum is extremely hard and refractory, but it softens and disintegrates in very old exposures, its position in the walls of ravines being usually indicated by a thin rust-colored band.

Fossils of 48 species have been identified from this layer in Ontario and Livingston counties. A full description of the pyrite lentils and a list of its fossils may be found in State Museum Bulletin 69, 1903 .

\section{GENESEE BLACK SHALE}

Overlying the pyrite layer or, in its absence, the Moscow shale, there is a bed of black bituminous shale similar in appearance to the Marcellus shale 500 feet lower in the strata. As commonly used, the term applied to these strata has included the succeeding Genundewa limestone, the dark West River shale and the black Middlesex shale above it. As here used, the term Genesee black shale designates the strata between the Tully horizon and the Genundewa limestone, which on these quadrangles have a total thickness of 85 to 90 feet. The shales are mostly densely black and contain a proportion of hydrocarbons sufficiently large to produce. when freshly broken, a natural fetid odor.

Pyrite in small nodules is common. Rows of spherical concretions and a few thin flags of fine grained calcareous sandstone, also occur.

Fossils, except a few plant remains, are almost entirely absent from the black shale and are rare in the lighter beds. The following have been obtained from the Genesee shale in this region:

Conodont teeth

Pleurotomaria rugulata Hall

Probeloceras lutheri Clarke

Bactrites aciculum (Hall)

Styliolina fissurella Hall

Pterochaenia fragilis ( $\mathrm{Hall}$ )

Lingula spatulata Hall

Orbiculoidea lodensis Hall

Liorhynchus quadricostatus Hall

Exposures of Genesee shale may be found on the Honeoye quadrangle in two ravines on the east side of the valley two miles north of the village of Honeoye, along the Hemlock outlet one to 
two miles north of Hemlock village, and in the ravine on the west side of Conesus lake near Eagle point,

\section{GENUNDEWA LIMESTONE}

This designation has been applied to a band of thin impure limestones separated by partings of a few inches or feet of black shale, the whole having a total thickness of six to eight feet.

Some of the limestone layers are very uneven and somewhat nodular, while others are even and compact; one of the latter, twelve to fourteen inches thick, has been utilized to a limited extent for building purposes.

The limestones are composed principally of the minute shells of the pteropod Styliolina $\mathrm{f}$ is surella Hall and the formation was formerly known as the "Styliola band." These shells give the limestone a sandy appearance after long exposure. This formation is exposed in two ravines two miles northeast of Honeoye and in the bed of Whetstone brook two miles northwest of Honeoye. It may be seen in a gully near the first bridge over the Hemlock outlet below Hemlock village, and in a larger ravine half a mile farther north. It appears fifty feet above the lake level in the ravine near Eagle point, Conesus lake.

Fossils are abundant in this formation, and the fauna is of peculiar interest owing to the appearance of many forms not known to occur in the rocks below.

A list of fossils numbering forty-eight species, obtained from the Genundewa strata, may be found in State Museum Bulletin ${ }^{6} 3$.

\section{WEST RIVER DARK SHALE}

Succeeding the Genundewa limestones there are 65 to 75 feet of dark gray shale in which there are interstratified beds of black shale one to three feet thick, at intervals of three to eight feet, which, in walls of ravines, give this formation a broadly banded appearance. Calcareous concretions are common; some of these are septaria and have been known under the names "petrified turtles," "niggerheads" and others of similar character.: A few thin flags of calcareous sandstone also occur.

At the top the passage to the succeeding black Middlesex shale is through several alternations of dark and black shale in a few feet.

The West River shales are exposed along Whetstone creek two miles northwest of Honeoye; in all the large ravines toward the 
west to Hemlock lake; on Conesus lake in the ravines between Old Orchard point and McPherson point, on the east side, and between Eagle point and Long point on the west side.

Fossils are rare in the West River beds. A few individuals of the following species occur:

Bactrites aciculum ( $\mathrm{Hall}$ )

Gephyroceŕas $s p$. ?

Pleurotomaria rugulata Hall

Buchiola retrostriata $v$. Buch

Pterochaenia fragilis ( $\mathrm{Hall}$ )

Lunulicardium curtum Hall

Panenka $s p$.

Lingula spatulata Vanuxem

Orbiculoidea lodensis Vanuxem

Melocrinus clarkei Hall

\section{MIDDLESEX BLACK SHALE}

A bed of black shale similar in appearance to the Genesee beds, succeeds the West River shales to the thickness of 30 to 35 feet. As the transition to the adjacent formations is gradual both above and below, the assigned thickness is somewhat arbitrary. It may be recognized beneath the lighter Cashaqua shale as far east as Cayuga county, where it ceases to be separable from the West River shale. Toward the west it is more distinctly differentiated from the adjacent formations and on the shore of Lake Erie it is a homogeneous band of black slaty shale six feet thick.

This formation is exposed in the ravines in the Honeoye Lake valley and in the region two miles south of Richmond Mills. It is finely displayed on the road one-half mile southeast of Hemlock and in the ravine at Glenville. It also appears in all of the ravines on both sides of Conesus lake in the vicinity of McPherson point.

Fossils are exceedingly rare in the Middlesex shale. The following occur :

Plant remains

Fish remains

Conodonts

Sandbergeroceras syngonum Clarke

Ontaria suborbicularis ( $\mathrm{Hall}$ ) 


\section{CASHAQUA SHALE}

The black shales are succeeded by nearly 200 feet of light colored bluish gray or olive shale, in which thin flags occur occasionally, and a few thin layers of black shale are interstratified. Calcareous concretions, and thin concretionary layers, continuous for but a short distance, are common in the higher portion of the formation.

Occupying a position between two heavy beds of black shale it is easily recognized by its lighter color and peculiar structure, wherever it is exposed, from Seneca lake to Lake Erie, and its peculiar and interesting fauna has made it the subject of careful study, the results of which, with a list of its fossils, may be found in State Museum Bulletin 63 and Memoir 6.

The Cashaqua beds are abundantly displayed in a very large number of ravines on these quadrangles. Among the more favorable and accessible exposures are the upper beds of Whetstone creek two miles west of Honeoye and the lower along the road half a mile southeast of Hemlock; along Canadice outlet above the Glenville mills; in Shurger's glen two and one-half miles west of Hemlock; in all of the large ravines on both sides of Conesus lake, and the upper beds at the mouth of the two large ravines on the east side of the valley half a mile south of the head of the lake.

\section{RHINESTREET BLACK SHALE}

The band of black shale that succeeds the Cashaqua shale and has a thickness on these quadrangles of 30 to 40 feet, was formerly known as the "upper black band." It was designated as above in State Museum Bulletin 63, from its exposure at the locality in the Canandaigua lake valley known as Rhinestreet, where it is 22 to 25 feet thick. It increases rapidly toward the west and on Lake Erie is 150 to 185 feet thick.

It is a well-defined band of slaty, bituminous black shale between formations of much lighter color, and, having greater power of resistance to erosive forces than those beds, it frequently produces cascades in the ravines along the line of outcrop.

It appears at most of the exposures of the upper Cashaqua beds in these quadrangles. It is seen to great advantage in the walls of the amphitheatre in the ravine of Whetstone creek half a mile south of the Honeoye-Hemlock road. It is also well exposed in Shurger's gully two and one-half miles west of Hemlock; in the two ravines half a mile south of the head of Conesus lake, east 
side, and in a Delaware, Lackawanna \& Western Railroad cut, at the west line of the Wayland quadrangle.

The fauna of the Rhinestreet shale is very limited. The following list shows the species that have been identified from it:

Polygnathus dubius Hinde

Prioniodus spicatus Hinde

P. erraticus Hinde

Palaeoniscus devonicus Clarke

Acanthodes pristis Clarke

Spathiocaris emersoni Clarke

Lunulicardium velatum Clarke

Pterochaenia fragilis ( $\mathrm{Hall}$ )

Leptodomus multiplex Clarke

Lingula $c f$. ligea

Plant remains are common, sometimes occurring in masses.

\section{HATCH SHALE AND FLAGS}

Next above the Rhinestreet shale there is a partial return to the conditions in the Cashaqua beds below, though the light shales are harder and less calcareous, and flags and thin sandstones are more frequent. A few bands of black shale are interbedded, but on the whole the principal lithologic difference between this formation and Cashaqua shale is in the proportion of sandy sediment, which is" considerably larger in these beds and increases upward to the top, where they are succeeded by the Grimes sandstones.

About 200 feet of strata are embraced within this formation, which was named from its abundant exposure on Hatch hill at Naples, Ontario county. There are many small exposures of these rocks in fields and ravines and along the highways, but only a few are sufficiently extensive to afford opportunity fo: satisfactory examination of them. The best are along the road, side and in a small ravine two miles southwest of Honeoye; in some small gullies on the west side of Canadice lake; along the roadsicle two miles north of Cemetery hill; in the north ravine near the head of Conesus lake, and the Calabogue ravine at Conesus, where the entire formation may be seen under favorable conditions. In the Canaseraga creek valley the lower part of all the ravines on the east side between West Sparta and Dansville show Hatch shales and flags. They also appear on the west side northward from Cumminsville. 
Fossils are very rare here. The softer shales in the lower beds contain a few forms like those found in the Cashaqua. The sandier beds are quite barren except of plant remains. The collector may expect to find:

Manticoceras pattersoni ( $\mathrm{Hall}$ )

Probeloceras lutheri Clarke

Lunulicardium ornatum Hall

Honeoyea desmata Clarke

Buchiola retrostriata ( $\%$. Buch)

Palaeotrochus praecursor Clarke

Bactrites

GRIMES SANDSTONE

This formation is composed principally of even layers of sandstone from six inches to three feet thick, some of which are rather soft and shaly, while others are hard and calcareous. The aggregate thickness is not far from fifty feet.

It appears on the next quadrangle toward the east in the Grimes gully at Naples, where it contains a small brachiopod fauna allied to the Ithaca fauna and other forms not known elsewhere.

Though these sandstones outcrop in many places on the Wayland quadrangle there are very few good exposures of the entire formation.

The entire section is shown in the Calabogue ravine below the lower bridge in the village of Conesus. The sandstones are quite barren of fossils except at the top, where a I4 to 16 inch layer is very hard, calcareous and concretionary and contains large irregularly shaped concretions so frequently as to almost form a continuous layer. It bears a close resemblance to a stratum in this horizon in Tannery gully, Naples, and like that one, contains brachiopod shells quite abundantly, but mostly in so fragmentary condition as to preclude identification.

Entire valves of a small Rhipidomella and Productella s p in u 1 i c os t a occur and loose spines of a larger Productella are abundant. Fragments of Liorhynchus may also be recognized.

The Grimes sandstones may be seen at the Delaware, Lackawanna \& Western Railroad culvert in the Culberson gully three and one-half miles north of Dansville, in other ravines and quarries in the east side of the Canaseraga valley, and on the west side at the mouth of the Bradner creek ravine half a mile northwest of Woodville. 


\section{GARDEAU FLAGS AND SHALE}

Light bluish gray sandstones and flags separated by beds of blue, olive or black shales succeed the Grimes sandstone for about 500 feet. In general stratigraphy this formation is much like the Hatch shale and flags, but many of the sandstones and some of the shale beds are thicker than are seen in that formation. It is the surface rock over a large area on these quadrangles, the drift cover of which, except in a few localities, is quite thin, and field outcrops are frequent. Almost innumerable ravines and small gullies on the hillsides show rock sections embracing some part of the Gardeau beds.

Among the best exposures on these quadrangles are: in Reynold's gulf, three miles north of Springwater; along Calabogue creek above the mill at Conesus; the Culberson ravine above the railroad; the Bradner creek ravine north of Woodville; and at Stones Falls and Stony brook glen south of Dansville.

Fossils are rare, but a few brachiopods known in the Ithaca fauna occur in some of the sandstones, and a few lamellibranchs and cephalopods common in the Cashaqua shales are found in soft shales, especially in the upper part of the formation.

The following is a partial list of the species occurring in the Gardeau beds :

Manticoceras oxy Clarke

Palaeotrochus praecursor Clarke

Grammysia elliptica Hall

Leptodesma robustum Hall

Productella lachrymosa Hall

P. spinulicosta Hall

Ambocoelia umbonata (Conrad)

Atrypa hystrix Hall

Orthothetes chemungensis Conrad

Liorhynchus mesacostalis Hall

Hydnoceras tuberosum Conrad

Aulopora $s p$.

Crinoid stems

\section{NUNDA SANDSTONE}

\section{(Portage sandstone of early reports)}

A heavy band of light bluish gray sandstone succeeds the Gardeau flags in central New York. It is a strongly marked feature of the stratigraphy of the region and is of considerable economic value as the source of fine building stone. 
The formation is nearly 200 feet thick in the Genesee river section, but thins out toward the west and barely reaches Lake Erie. It is less homogeneous toward the east, some parts becoming shaly, but it is traceable to the Seneca lake valley.

On the Genesee river and farther west fossils, except plant remains, are extremely rare, but on the Wayland quadrangle and eastward, there are found lenticular masses of crinoidal limestone that contain brachiopods and other fossils in large numbers.

Except in the southern part of the Wayland quadrangle, the position of these sandstones is too high to permit of good exposures, but they are well displayed for nearly a mile along the Pittsburg, Shawmut \& Northern Railroad two miles southeast of Perkinsville. Extensive quarries on the hill east of Dansville are in these beds, and they have also been quarried on the south face of the hill one and one-half miles north of Perkinsville. Blocks from a fossiliferous lentil at the south end of the hill four miles east of Wayland have been utilized as firestone in that vicinity. Calcareous slabs from this lens, or possibly another one, lie on the north face of the hill one and one-half miles southeast of Wayland.

The fossils contained in these lentils have not been listed, except in the case of the large one on High point on the Naples quadrangle three miles east of this quadrangle, from which 32 species have been obtained. For list, see State Museum Bulletin 63 .

\section{WISCOY BEDS}

About 200 feet of light and dark shales and soft sandstones that contain a fauna bearing some resemblance to that of the normal Portage and on that account have been considered as a separate formation, succeed the Nunda sandstone on the Genesee river. Though acquiring an increase of sandy material and appearing mainly as a bed of rather soft-olive sandstone, on the Wayland quadrangle this formation is readily distinguished from the harder, lighter colored and usually more fossiliferous sandstones and harder shales of the normal Chemung beds by which it is overlain.

There is a small exposure of Wiscoy beds by the side of the Pittsburg \& Shawmut Railroad where it crosses the south line of the quadrangle, and a more extensive one from two miles south of Patchenville to the south line of the quadrangle. Crinoid stems, small brachiopods and a small Orthoceras occur here. The large cephalopod Manticoceras oxy Clarke appears occasionally in these beds. 
With the increase of sand in the sedimentation toward the east, a few brachiopods which are not found at Wiscoy appear.

\section{CHEMUNG SHALE AND SANDSTONE}

About 450 feet of the lower beds of this formation compose the surface rock on the high land in the extreme southern part of the Wayland quadrangle. In lithologic character they are not materially different from the Gardeau beds, except that the sandstones are lighter colored and more micaceous.

Fossils are rare in the lower 300 feet but are in very great abundance in the higher sandstones exposed on this quadrangle. These may be seen to good advantage along the roadside threefourths of a mile northeast of Loon lake, where the rock is crowded with large brachiopods. Hydnoceras nodosum Hall occurs here also.

The rock lies near the surface over this region and small field exposures are frequent, but there are no extensive outcrops.

\section{DIP}

The average dip of the base of the Onondaga limestone between Honeoye Falls and the salt shaft at Livonia is about 33 feet per mile toward the south. On an east and west line, though made variable by frequent undulations of the strata, this limestone is on the whole nearly level.

As all of the formations above the Onondaga up to the Wiscoy shale, except the Stafford limestone and the Rhinestreet black shale, thin out more or less rapidly toward the west, the dip in that direction varies also with the contact line used as a base, but is nowhere appreciable except on careful measurement. The deep and narrow valleys partly occupied by Conesus, Hemlock and Honeoye lakes are blocked at the south ends by enormous beds of gravel, sand and clay which compose a part of the great moraine of the second glacial epoch. The areas intervening between the lakes and the moraine are level beds of rich alluvium. The Genesee river valley in the northwest corner of the Honeoye quadrangle; the Canaseraga valley near Dansville; the bed of a small lake near Wayland and another at South Lima, are of similar character.

A striking exhibition of the force of glacial action occurs in a small amphitheatrical valley of Stony brook at Five Corners, four miles west of Honeoye Falls. The bed rock, Bertie waterlime, is 
but slightly exposed, but a very large squantity of Lockport dolomite has been transported southward a distance of at least twelve miles and deposited here. The sloping bank on the east side of the little valley is almost covered by blocks of the brown scraggly rock, some of which are twelve to fifteen feet across and six to eight feet thick. They lie so close together that they present the appearance of a broken escarpment, extending toward the north for 60 to 70 rods.

Large blocks of the dolomite are common in this vicinity and a morainic mass of this rock covers several acres half a mile west of this locality, but is mostly in smaller blocks. 



\section{IN D EX}

Acanthodes pristis, 20.

Actinopteria sp., I2. muricata, I0, I2.

Allens Hill, I4.

Ambocoelia praeumbona, Io. umbonata, I0, 12, 22.

Ashantee, II.

Aspidicthys, Io.

Athyris spiriferoides, Io.

Atrypa hystrix, 22. reticularis, 8 , 12 .

Attica quadrangle, 14.

Aulopora sp., 22.

Aviculopecten bellus, I2. cf. fasciculatus, Io.

Avon, II, I4.

\section{Bactrites, 2I.}

aciculum, I6, I8.

Beebe brook, 15 .

Bellerophon leda, I2, I3.

Bertie waterlime, 6, 7, 24 .

Bradner creek ravine, 21, 22.

Brockport quadrangle, 7 .

Buchiola retrostriata, I2, I8, 21 .

Calabogue ravine, 20, 21, 22.

Canarotoechia horsfordi, I2. sappho, 12.

Camillus shale, 6-7.

Canadice lake, I9, 20.

Canandaigua quadrangle, $7, \mathrm{I} 4, \mathrm{I} 5$.

Canaseraga valley, 20, 2I, 24.

Cardiff shale, 6, 12-13.

Cashaqua shale, 6, 18, 19, 20.

Cemetery hill, 20.

Centerfield, I4.

Chemung shalc and sandstone, 6,23 , 24.

Chonetes deflectus, II.

lepidus, I3.

lineatus, II.

mucronatus, I0, I2, I3.

scitulus, I2, 13 .

$c f$. yandellanus, II.
Cobleskill waterlime, 7 .

Coelospira camilla, Io.

Conesus, 20, 21, 22.

Conesus lake, 17, 18, 19, 20, 24.

Conesus outlet, II.

Conodonts, I6, 18.

Crinoid stems, 13, 22, 23.

Cryphaeus boothi, I3.

Culberson gully, 21, 22.

Cumminsville, 20.

Cypricardinia indenta, 10.

Cyrtoceras $s p$. ., 12.

citum, Io.

Dansville, 20, 21, 22, 23, 24.

Diaphorostoma lineatum, I5.

Dinichthys halmodeus, Io.

Dip of strata, 24.

Eagle point, 17, 18.

Eridophyllum $s p .$, I5.

Favosites, 8.

arbusculus, 15.

argus, 15.

Fish remains, 18.

Five Corners, 7, 9, 24.

Flint creek, II.

\section{Garbuttsville, 7 .}

Gardeau flags and shale, 6, 22, 24 .

Gates creek, I4, 15.

Genesee black shale, 6, I6, 17 .

Genesee Lime Company, 9.

Genesee river valley, 24.

Genundewa limestone, 6, 16, I7.

Gephyroceras sp., I8.

Glacial action, exhibition of force, 24.

Glenville, 18, I9.

Gomphoceras, $s p$., I3.

Gorham, 15 .

Grammysia elliptica, 22.

Grimes sandstone, 6, 20, 21, 22. 
Hatch hill, 20.

Hatch shale and flags, 6, 20, 21.

Heliophyllum halli, I5.

Hemlock, I7, I8, I9.

Hemlock lake, I8, 24.

Hemlock outlet, $7,8,15,16,17$.

Hipparionyx proximus, 8 .

Honeoye, I6, I7, I9, 20.

Honeoye creek, 9.

Honeoye Falls, 7, 8, 9.

Honeoye lake, 18, 24.

Honeoyea desmata, 21.

Hydnoceras nodosum, 24.

tuberosum, 22.

\section{Lancaster, II.}

Leperditia alta, 7,8 .

Leptodesma robustum, 22.

Leptodomus multiplex, $2 \mathrm{c}$.

Leptostrophia perplana, Io.

Lingula $c f$. ligea, 20. spatulata, I6, I8.

Liopteria laevis, I0, I2, I3. rugosa, 8.

Liorhynchus, 2 I. limitare, IO, I3. mesacostalis, 22. multicostum, I3. quadricostatus, I6.

Little Conesus creek, II, I2, I3, I4.

Livonia salt shaft, $8,9,12,13,14,15$.

Lockport dolomite, 25.

Long point, I8.

Loon lake, 24.

Loxonema delphicola, II.

Ludlowville shale, 6, I4.

Lunulicardium curtum, I8. ornatum, 2 I.

velatum, 20.

Lyriopecten orbiculatus, I5.

McPherson point, I8.

Manticoceras oxy, 22, 23.

pattersoni, 2 I.

Marcellus black shale, 6, 9, II.

Megistocrinu', 15 .

Melocrinus clarkei, I8.

Meristella barrisi, II.

Microdon bellistriatus, ro.

Middlesex black shale, 6, I6, I7, I8.
Modiella pygmaea, I2.

Modiomorpha concentrica, Io. subalata, I0, I3.

Monroe milldam, 9.

Moscow shale, 6, I5, I6.

Naples, 20, 2 I.

Naples quadrangle, 23.

North Bloomfield, 9.

Nuculites nyssa, Io.

oblongatus, Io.

triqueter, 13.

Nunda sandstone, 6, 22, 23.

Old Orchard point, I8.

Onondaga limestone, $6,7,8-9,24$.

Ontario suborbicularis, 18 .

Orbiculoidea lodensis, I6, 18. minuta, I0, I3.

Oriskany sandstone, 6,8 .

Orthis $c f$. lenticularis, II. $c f$. propinqua, 8.

Orthoceras aedipus, II. caelamen, 14. exile, 13.

incarceratum, Io.

lima, ro.

cf. marcellense, II.

nuntium, IO, I2.

subulatum, I0, I2.

Orthonota undulata, 13.

Orthothetes arctostriatus, I2.

bellulus, I I.

chemungensis, 22.

pandora, II.

Palaeoniscus devonicus, 20.

Palaeoneilo fecunda, I3. plana, Io.

Paleotrochus praecursor, 2I, 22.

Panenka $s p$. , I8. equilatera, I0, I2, I3.

lincklaeni, I0, I2.

Patchenville, 23.

Pentagonia unisulcata, 8.

Pentamerella $c f$. arata, 8.

Perkinsville, 23.

Phacops rana, IO, II, I3, I4.

Pholidops hamiltoniae, II.

Plant remains, I8, 20. 
Pleurotomaria capillaria, I2. itys, II.

lucina, Io, II.

rugulata, I0, I2, I3, I6, I8. sulcomarginata, II.

Polygnathus dubius, 20.

Portage sandstone, 22.

Prioniodus erraticus, 20. spicatus, 20.

Probeloceras lutheri, 16, 21.

Productella, 2 I.

lachrymosa, 22.

spinulicosta, 13, 21, 22.

Pterinopecten dignatus, IO, I3. exfoliatus, 12 .

Pterochaenia fragilis, I0, I2, I3, 16, I8, 20.

Pyrite layer, Tully horizon, 6, I5, I6.

Reptaria stolonifera, I3.

Reynold's gulf, 22.

Rhinestreet black shale, 6, 19-20, 24 . Rhipidomella, 21.

Richmond Mills, I5, I8.

Sandbergeroceras syngonium, I8.

Shurger's glen, 19.

Skaneateles shale, 6, I3.

South Lima, 24.

Spathiocaris emersoni, 20.

Spirifer $c f$. arenosus, 8.

audaculus, I0, I2.

granulosus, 15 .

mucronatus, I5. supaumbona, 12.

vanuxemi, 8.

Spring creek, 7, 9.

Springwater, 22.

Stafford limestone, 6, 9, II-I2, 24.

Stereolasma rectum, II.

Stictopora incisurata, II.

Stones Falls, 22.

Stony brook, 7, 9, 22, 24.

Strophalosia truncata, I2, I3.

Stropheodonta $s p ., 8$.

inequistriata, Io.

varistriata, 8.

Styliolina fissurella, I0, I2, 13, I6, I7.

Tentaculites gracilistriatus, 10.

Terebratula, $s p$. Io.

Tichenor limestone, 6, 14, 15 .

Tornoceras uniangulare, I0, I2, I3.

Tropidoleptus carinatus, Io.

Tully horizon, pyrite layer, 6, I5, I6.

Victor, 7 .

Wayland, 23, 24.

Wayland quadrangle, 20, 21, 23, 24 .

West River shale, 6, I6, 17.

West Sparta, 20.

Wheatland, 7.

Whetstone creek, I7, I9.

Whitfieldella laevis, 7 .

Wiscoy shale, 6, 23.

Woodville, 2I, 22. 
$\because 3,34$

a.s. 


\title{
New York State Education Department
}

\section{New York State Museum}

\author{
John M. Clarke, Director \\ PUBLICATIONS
}

Packages will be sent prepaid except when distance or weight renders the same impracticable. On ro or more copies of any one publication $20 \%$ discount will be given. Editions printed are only large enough to meet special claims and probable sales. When the sale copies are exhausted, the price for the few reserve copies is advanced to that charged by secondhand booksellers, in order to limit their distribution to cases of special need. Such prices are inclosed in [ ]. All publications are in paper covers, unless binding is specified. Checks or money orders should be addressed and payable to New York State Education Department.

Museum annual reports 1847 -date. All in print to $1894,50 \mathrm{c}$ a volume, $75 \mathrm{c}$ in cloth; 1894-date, sold in sets only; 75c each for octavo volumes; price of quarto volumes on application.

These reports are made up of the reports of the Director, Geologist, Paleontologist, Botanist and Entomologist, and museum bulletins and memoirs, issued as advance sections of the reports.

Director's annual reports I904-date.

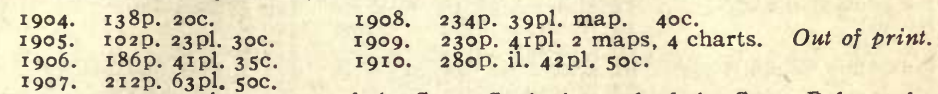

These reports cover the reports of the State Geologist and of the State Palcontologist. Bound also with the museum reports of which they form a part.

Geologist's annual reports I88I-date. Rep'ts I, 3-r3, I7-date, 8vo; 2 ,

$$
\text { r 4-I } 6 \text {, } 4 \text { to. }
$$

In 1898 the paleontologic work of the State was made distinct from the geologic and was reported separately from $1899-1903$. The two departments were reunited in 1904 , and are now reported in the Director's report.

The annual reports of the original Natural History Survey, $1837-41$, are out of print.

Reports $I-4,188 \mathrm{I}-84$, were published only in separate form. Of the 5 th report 4 pages were reprinted in the 39 th museum report, and a supplement to the 6 th report was included in the 4 oth museum report. The 7 th and subsequent reports are included in the $4 \mathrm{rst}$ and following museum reports, except that certain lithographic plates in the I Ith report (r89r) and $x_{3}$ th $(1893)$ are omitted from the 45 th and 47 th museum reports.

Separate volumes of the following only are a vailable.

$\begin{array}{lccccc}\text { Report } & \text { Price } & \text { Report } & \text { Price } & \text { Report } & \text { Price } \\ \text { I 2 (1892) } & \$ .50 & 17 & \$ .75 & 21 & \$ .40 \\ \text { I4 } & .75 & 18 & .75 & 22 & .40 \\ \text { I5, 2V. } & 2 & 19 & .40 & .45 \\ \text { I6 } & \text { I } & 20 & .50 & \text { [See Director's annual reports] }\end{array}$

\section{Paleontologist's annual reports r899-date.}

See first note under Geologist's annual reports.

Bound also with museum reports of which they form a part. Reports for 1899 and 1900 may be had for 200 each. Those for $1901-3$ were issued as bulletins. In 1904 combined with the Director's report.

Entomologist's annual reports on the injurious and other insects of the State of New York i 882 -date.

Reports $3-20$ bound also with museum reports $40-46,48-58$ of which they form a part. Since 1898 these reports have been issued as bulletins. Reports $3-4$, I7 are out of print, other reports with prices are: 


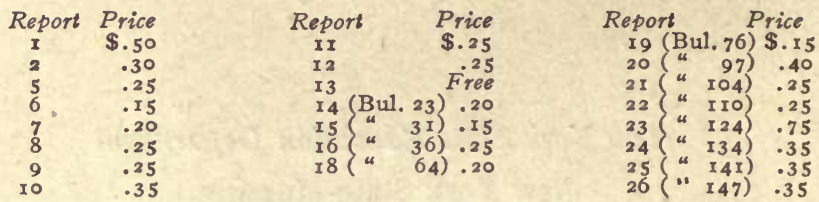

Reports $2,8-12$ may also be obtained bound in cloth at $25 \mathrm{c}$ each in addition to the price given above.

Botanist's annual reports 1867 -date.

Bound also with museum reports $2 \mathrm{I}$-date of which they form a part; the first Botanist's report appeared in the 2 Ist museum report and is numbered $2 I$. Reports $2 I-24,29,3 I-4 I$ were not published separately.

Separate reports for $1871-74,1876,1888-98$ are out of print. Report for 1899 may be had for 20C; I 900 for $50 \mathrm{C}$. Since I90I these reports have been issued as bulletins.

Descriptions and illustrations of edible, poisonous and unwholesome fungi of New York have also been published in volumes $I$ and 3 of the 48 th (1894) museum report and in volume I of the 49 th (1895), 5 Ist (1897), 52d (1898), 54th (I900), 55th (I90I), in volume 4 of the $56 \mathrm{th}$ (1902), in volume 2 of the 57 th (1903), in volume 4 of the 58 th (1904), in volume 2 of the 59 th (1905), in volume 1 of the 6oth (1906), in volume 2 of the 6rst (1907), 62d (1908), 63d (r909) reports. The descriptions and illustrations of edible and unwholesome species contained in the $49 \mathrm{th}, 5 \mathrm{Ist}$ and $52 \mathrm{~d}$ reports have been revised and rearranged, and, combined with others more recently prepared, constitute Museum Memoir 4.

Museum bulletins r887-date. 8vo. To advance subscribers, $\$ 2$ a year or $\$ \mathbf{I}$ a year for division (1) geology, economic geology, paleontology, mineralogy; $50 c$ each for division (2) general zoology, archeology, miscellaneous, (3) botany, (4) entomology.

Bulletins are grouped in the list on the following pages according to divisions.

The divisions to which bulletins belong are as follows:

I Zoology

2 Botany

3 Economic Geology

4 Mineralogy

5 Entomology

7 Economic Geology

8 Botany

Zoology

ro Economic Geology

II

12

13 Entomology

14 Geology

$x 5$ Economic Geology

I 6 Archeology

I 7 Economic Geology

18 Archeology

I9 Geology

20 Entomology

2 I Geology

22 Archeology

23 Entomology

24

25 Botany

26 Entomology

27

28 Botany

29 Zoology

30 Economic Geology

3 I Entomology

32 Archeology

33 Zoology

34 Paleontology

35 Economic Geology

36 Entomology

37

38 Zoology

39 Paleontology

40 Zoology

41 Archeology

42 Paleontology

43 Zoology

44 Economic Geology

45 Paleontology

46 Entomology

47 Geology

49 Paleontology

50 Archeology

5 I Zoology
52 Paleontology

53 Entomology

54 Botany

55 Archeology

56 Geology

57 Entomology

58 Mineralogy

59 Entomology

6o Zoology

6I Economic Geology

62 Miscellaneous

63 Paleontology

64 Entomology

65 Paleontology

66 Miscellaneous

67 Botany

68 Entomology

69 Paleontology

70 Mineralogy

7 I Zoology

72 Entomology

73 Archeology

74 Entomology

75 Botany

76 Entomology

77 Geology

78 Archeology

79 Entomology

8o Paleontology

$8 \mathrm{r}$

$8 \mathrm{r}$

83 Geology

85 Economic Geology

86 Entomology

87 Archeology

88 Zoology

89 Archeology

90 Paleontology

or Zoology

92 Paleontology

93 Economic Geology

94 Botany

95 Geology

96

97 Entomology

98 Mineralogy

99 Paleontology

roo Economic Geology

I or Paleontology

ro2 Economic Geology

\author{
103 Entomology \\ I05 Botany \\ Io6 Geology \\ 107 \\ ro8 Archeology \\ rog Entomology \\ Iro \\ I I Geology \\ I 2 Economic Geology \\ I 3 Archeology \\ I 4 Paleontology \\ I 5 Geology \\ I 6 Botany \\ I 7 Archeology \\ I 8 Paleontology \\ I 9 Economic Geology \\ I 20 \\ I 2 I Director's report for 1907 \\ I 2 Botany \\ I 23 Economic Geology \\ I 24 Entomology \\ 25 Archeology \\ I 26 Geology \\ 127 \\ I 28 Paleontology \\ I 29 Entomology \\ I 30 Zoology \\ I I Botany \\ r32 Economic Geology \\ I33 Director's report for 1908 \\ I34 Entomology \\ I3 Geology \\ I36 Entomology \\ I37 Geology \\ 138 \\ I39 Botany \\ I 40 Director's report for r 909 \\ I 4 I Entomology \\ 142 Economic geology \\ I 43 \\ 144 Archeology \\ 145 Geology \\ 146 \\ 147 Entomology \\ 48 Geology \\ I 49 Director's report for roro \\ $r$ o Botany \\ I5 I Economic Geology \\ I52 Geology ?
}


- Bulletins are also found with the annual reports of the museum as follows:

\begin{tabular}{|c|c|c|c|c|c|c|c|}
\hline Bulletin & Report & Bulletin & Report & Bulletin & Report & Bulletin & Report \\
\hline $12-15$ & 48, v. I & 72 & $57, \mathrm{v}, \mathrm{r}, \mathrm{pt} 2$ & 102 & 59, v. I & 134 & 62, v. 2 \\
\hline I6, I 7 & 50, V. I & 73 & 57, v. 2 & $103-5$ & 59, v. 2 & 135 & $63, v, I$ \\
\hline I 8, I9 & $5 \mathrm{I}$, V. I & 74 & 57, v. I, pt 2 & 106 & 59 , v. I & 136 & $63, v .2$ \\
\hline $20-25$ & 52, v. I & 75 & 57, v. 2 & 107 & $60, v, 2$ & 137 & 63, V. I \\
\hline $26-3 I$ & 53, v. I & 76 & 57, v. 1, pt 2 & 108 & 60, v. 3 & 138 & 63, v. I \\
\hline $32-34$ & 54, V. I & 77 & 57, v. I, pt $x$ & $109, x 10$ & $60, \mathrm{~V} . \mathrm{I}$ & 139 & $63, v, 2$ \\
\hline 35,36 & 54, v. 2 & 78 & 57, v. 2 & III & $60, v \cdot 2$ & 140 & $63, v, x$ \\
\hline $37-44$ & 54, v. 3 & 79 & 57, v. I, pt 2 & II 2 & 60, V. I & I 41 & $63, v, 2$ \\
\hline $45-48$ & 54, v. 4 & 80 & 57, v. I, pt $x$ & II3 & $60, v, 3$ & 142 & 63, v. 2 \\
\hline $49-54$ & 55, v. I & 81,82 & 58, v. 3 & I I 4 & $60, v$. I & 143 & $63, v, 2$ \\
\hline 55 & 56, v. 4 & 83,84 & 58, V. I & II 5 & 60, v. 2 & & \\
\hline & 56, v. I & 85 & 58, v. 2 & I 6 & $60, v . I$ & Memoir & \\
\hline 57 & 56, v. 3 & 86 & 58, v. 5 & II 7 & $60, v, 3$ & 2 & $49, v, 3$ \\
\hline 58 & 56, V. I & $87-89$ & 58, v. 4 & II 8 & 60, V. I & 3,4 & 53, v. 2 \\
\hline 59,60 & 56, v. 3 & 90 & 58, v. 3 & II $9-2 I$ & $6 \mathrm{I}, \mathrm{V} . \mathrm{I}$ & 5,6 & 57, v. 3 \\
\hline $6 I$ & 56, v. I & $9 I$ & 58, v. 4 & 122 & $61, v, 2=$ & & 57, v. 4 \\
\hline 62 & $56, v .4$ & 92 & 58, v. 3 & I 23 & $6 \mathrm{I}, \mathrm{V} . \mathrm{I}$ & $8, p t$ I & 59, v. 3 \\
\hline 63 & 56, v. 2 & 93 & 58, v. 2 & 124 & $6 I, v .2$ & $8, p t 2$ & 59, v. 4 \\
\hline 64 & $56, v .3$ & 94 & 58, v. 4 & 125 & $62, v \cdot 3$ & 9, pt I & $60, v .4$ \\
\hline & $56, v, 2$ & 95,96 & 58 , v. I & $126-28$ & 62, V. I & $9, \mathrm{pt} 2$ & $62, v, 4$ \\
\hline 66 & 56, v. 4 & & 58, v. 5 & 129 & $62, v .2$ & Io & $60, v \cdot 5$ \\
\hline & $56, v .3$ & 98,99 & 59, v. 2 & 130 & $62, v \cdot 3$ & I I & $6 x, v .3$ \\
\hline 69 & 56, v. 2 & 100 & 59, v. I & I3 I, I32 & 62, v. 2 & 12 & $63, v .3$ \\
\hline 70,71 & 57, v. I, pt I & IOI & 59, v. 2 & 133 & 62, V. I & $I_{3}$ & 63, v. 4 \\
\hline
\end{tabular}

The figures at the beginning of each entry in the following list indicate its number as a museum bulletin.

Geology. I4 Kemp, J. F. Geology of Moriah and Westport Townships' Essex Co. N. Y., with notes on the iron mines. $38 \mathrm{p}$. il. $7 \mathrm{pl} .2$ maps. Sept. r 895 . Free.

I9 Merrill, F. J. H. Guide to the Study of the Geological Collections of the New York State Museum. I64p. I I9pl. map. Nov. I898. Out of print. 2 I Kemp, J. F. Geology of the Lake Placid Region. 24p. rpl. map. Sept. 1898 . Free.

48 Woodworth, J. B. Pleistocene Geology of Nassau County and Borough of Queens. $58 \mathrm{p}$. il. $8 \mathrm{pl}$. map. Dec. I90 r. $25 \mathrm{c}$.

56 Merrill, F. J. H. Description of the State Geologic Map of rgor. 42p. 2 maps, tab. Nov. I902. Free.

77 Cushing, H. P. Geology of the Vicinity of Little Falls, Herkimer Co. 98p. il. I 5 pl. 2 maps. Jan. I905. 30c.

83 Woodworth, J. B. Pleistocene Geology of the Mooers Quadrangle. 62p. $25 \mathrm{pl}$. map. June 1905 . $25 \mathrm{C}$.

84 Ancient Water Levels of the Champlain and Hudson Valleys. $206 \mathrm{p}$. il. I r pl. I 8 maps. July I905. 45c.

95 Cushing, H. P. Geology of the Northern Adirondack Region. r88p. I 5pl. 3 maps. Sept. I905. 30c.

96 Ogilvie, I. H. Geology of the Paradox Lake Quadrangle. 54p. il. I 7 pl. map. Dec. I905. 30c.

Io6 Fairchild, H. L. Glacial Waters in the Erie Basin. 88p. ז4pl. 9 maps. Feb. 1907. Out of print.

ro7 Woodworth, J. B.; Hartnagel, C. A.; Whitlock, H. P.; Hudson, G. H.; Clarke, J. M.; White, David \& Berkey, C. P. Geological Papers. 388p. 54pl. map. May r.907.-90c, cloth.

Contents: Woodworth, J. B. Postglacial Faults of Eastern New York.

Hartnagel, C. A. Stratigraphic Relations of the Oneida Conglomerate.

Upper Siluric and Lower Devonic Formations of the Skunnemunk Mountain Region.

Whitlock, H. P. Minerals from Lyon Mountain, Clinton Co.

Hudson. G. H. On Some Pelmatozoa from the Chazy Limestone of New York.

Clarke, J. M. Some New Devonic Fossils.

An Interesting Style of Sand-filled Vein.

- Eurypterus Shales of the Shawangunk Mountains in Eastern New York.

White, David. A Remarkable Fossil Tree Trunk from the Middle Devonic of New York.

Berkey, C. P. Structural and Stratigraphic Features of the Basal Gneisses of the Highlands.

I I Fairchild, H. L. Drumlins of New York. 6op. 28pl. ig maps. July I907. Out of print.

Ir 5 Cushing, H. P. Geology of the Long Lake Quadrangle. 88p. 20 pl. map. Sept. 1907. Out of print. 
I26 Miller, W. J. Geology of the Remsen Quadrangle. 54p. il, I I pl. ma p Jan. $1909.25 \mathrm{c}$.

127 Fairchild, H. I. Glacial Waters in Central New York. 64p. 27 pl. I 5 maps. Mar. 1909. $40 \mathrm{c}$.

r35 Miller, W. J. Geology of the Port Leyden Quadrangle, Lewis County, N. Y. 62 p. il. I I pl. map. Jan. I9ro. $25 \mathrm{c}$.

137 Luther, D. D. Geology of the Auburn-Genoa Quadrangles. 36p. map. Mar. rgro. 2oc.

I38 Kemp, J. F. \& Ruedemann, Rudolf. Geology of the Elizabethtown and Port Henry Quadrangles. I 76p. il. 2opl. 3 maps. Apr. 1910. 40c.

145 Cushing, H. P.: Fairchild, H. L.; Ruedemann, Rudolf \& Smyth, C. H. Geology of the Thousand Islands Region. I94p. il.62pl. 6 maps. Dec. I9ro. $75 \mathrm{c}$.

I46 Berkey, C. P. Geologic Features and Problems of the New York City (Catskill) Aqueduct. 286p. il. 38pl. maps. Feb. I9 I r. 75c; cloth, \$r.

148 Gordon, C. E. Geology of the Poughkeepsie Quadrangle. 122p. il. 26 pl. map. Apr. rgri. 30c.

152 Luther, D. D. Geology of the Honeoye-Wayland Quadrangles. 30 p. map. Oct. I9II. 20c.

Economic geology. 3 Smock, J. C. Building Stone in the State of New York. I54p. Mar. I888. Out of print.

7 First Report on the Iron Mines and Iron Ore Districts in the State of New York. $78 \mathrm{p}$. map. June r 889. Out of print.

ro - Building Stone in New York. 2 rop. map, tab. Sept. r89o. $40 \mathrm{c}$.

I Merrill, F. J. H. Salt and Gypsum Industries of New York. 94p. r 2 pl. 2 maps, i I tab. Apr. I 893. [50c]

12 Ries, Hein rich. Clay Industries of New York. I74p. il. Ipl. map. Mar. I 895 . $30 \mathrm{c}$.

15 Merrill, F. J. H. Mineral Resources of New York. 240 p. 2 maps. Sept. I 895 . [50c]

17 Road Materials and Road Building in New York. 52p. I4pl. 2 maps. Oct. 1897 . $15 \mathrm{c}$.

30 Orton, Edward. Petroleum and Natural Gas in New York. 136p. il. 3 maps. Nov. I899. I 5 c.

35 Ries, Heinrich. Clays of New York; their Properties and Uses. $456 \mathrm{p}$. r 40 pl. map. June 1900. Out of print.

$44-$ Lime and Cement Industries of New York; Eckel, E. C. Chapters on the Cement Industry. 332 p. rorpl. 2 maps. Dec. r 901 . 85c, cloth.

6r Dickinson, H. T. Quarries of Bluestone and Other Sandstones in New York. I I 4 p. $18 \mathrm{pl} .2$ maps. Mar. $1903.35 \mathrm{c}$.

85 Rafter, G. W. Hydrology of New York State. 902p. il. 44pl. 5 maps. May r 905. \$1.50, cloth.

93 Newland, D. H. Mining and Quarry Industry of New York. $78 \mathrm{p}$. July r 905 . Out of print.

roo McCourt, W. E. Fire Tests of Some New York Building Stones. $40 \mathrm{p}$. $26 \mathrm{pl}$. Feb. 1906. $15 \mathrm{c}$.

102 Newland, D. H. Mining and Quarry Industry of New York 1905. I62p. June 1906. $25 \mathrm{c}$.

II2 - Mining and Quarry Industry of New York I906. 82p. July 1907. Out of print.

II9 - \& Kemp, J. F. Geology of the Adirondack Magnetic Iron Ores with a Report on the Mineville-Port Henry Mine Group. I84p. I $4 \mathrm{pl}$. 8 maps. Apr. I908. $35 \mathrm{c}$.

I 20 Newland, D. H. Mining and Quarry Industry of New York 1907. 82p. July r 908 , Out of print.

123 \& Hartnagel, C. A. Iron Ores of the Clinton Formation in New York State. $76 \mathrm{p}$. il. I 4 pl. 3 maps. Nov. I $908.25 \mathrm{c}$.

132 Newland, D. H. Mining and Quarry Industry of New York rgo8. 98p. July r 909 . I $5 \mathrm{c}$.

$142-$ Mining and Quarry Industry of New York for 1909. 98p. Aug. I910. I5C.

I43 - Gypsum Deposits of New York. 94p. 20pl. 4 maps. Oct. I9ro. $35 \mathrm{c}$.

I5I - Mining and Quarry Industry of New York I9io. 82p. June I9II. 
Mineralogy. 4 Nason, F. L. Some New York Minerals and their Localities. 2 2p. Ipl. Aug. 1888. Free.

58 Whitlock, H. P. Guide to the Mineralogic Collections of the New York State Museum. I5op. il. 39pl. II models. Sept. I902. $40 \mathrm{c}$.

70 - New York Mineral Localities. r rop. Oct. Igo3. 20c.

98 - Contributions from the Mineralogic Laboratory. 38p. $7 \mathrm{pl}$. Dec. I905. Out of print.

Paleontology. 34 Cumings, E. R. Lower Silurian System of Eastern Montgomery County; Prosser, C. S. Notes on the Stratigraphy of Mohawk Valley and Saratoga County, N. Y. 74p. I4pl. map. May igoo. I5c. 39 Clarke, J. M. Simpson, G. B. \& Loomis, F. B. Paleontologic Papers I. 72 p. il. I6pl. Oct. I900. I5c.

Contents: Clarke, J. M. A Remarkable Occurrence of Orthoceras in the Oneonta Beds of the Chenango Valley, N. Y.

Paropsonema cryptophya; a Peculiar Echinoderm from the Intumescens-zone (Portage Beds) of Western New York.

- Dictyonine Hexactinellid Sponges from the Upper Devonic of New York.

Simpson, G. B. Preliminary Descriptions of New Genera of Paleozoic Rugose Corals.

Loomis, F. B. Siluric Fungi from Western New York.

42 Ruedemann, Rudolf. Hudson River Beds near Albany and their Taxonomic Equivalents. II6p. 2pl. map. Apr. I90 I. $25 \mathrm{c}$.

45 Grabau, A. W. Geology and Paleontology of Niagara Falls and Vicinity. 286p. il. r 8pl. map. Apr. 1901. 65c; cloth, $90 \mathrm{c}$.

49 Ruedemann, Rudolf; Clarke, J. M. \& Wood, Elvira. Paleontologic Papers 2. 240p. I3pl. Dec. I901. Out of print.

Contents: Ruedemann, Rudolf. Trenton Conglomerate of Rysedorph Hill.

Clarke, J. M. Limestones of Central and Western New York Interbedded with Bituminous Shales of the Marcellus Stage.

Wood, Elvira. Marcellus Limestones of Lancaster, Erie Co., N. Y.

Clarke, J. M. New Agelącrinites.

Value of Amnigenia as an Indicator of Fresh-water Deposits during the Devonic of New York, Ireland and the Rhineland.

52 Clarke, J. M. Report of the State Paleontologist r9o.r. 280p. il. "1opl, map, I tab: July I902. 40c.

63 - \& Luther, D. D. Stratigraphy of Canandaigua and Naples Quadrangles. $78 \mathrm{p}$. map. June r9o4. $25 \mathrm{c}$.

65 Clarke, J. M. Catalogue of Type Specimens of Paleozoic Fossils in the New York State Museum. 848p. May 1903. \$1.20, cloth.

$69-$ Report of the State Paleontologist I902. 464p. 52 pl. 7 maps. Nov. I903. \$I, cloth.

80 Report of the State Paleontologist Igo3. 396p. 29pl. 2 maps. Feb. I905. 85c, cloth.

8I \& Luther, D. D. Watkins and Elmira Quadrangles. 32p. map. Mar. I $905.25 \mathrm{c}$.

82 - Geologic Map of the Tully Quadrangle. 40p. map. Apr. r905. $20 \mathrm{c.}$

90 Ruedemann, Rudolf. Cephalopoda of Beekmantown and Chazy Formations of Champlain Basin. 224p. il. $38 \mathrm{pl}$. May I906. 75c, cloth.

92 Grabau, A. W. Guide to the Geology and Paleontology of the Schoharie Region. 3 I 4 p. il. $26 \mathrm{pl}$. map. Apr. I906. 75c, cloth.

99 Luther, D. D. Geology of the Buffalo Quadrangle. 32p. map. May I $906.20 \mathrm{C}$.

ror Geology of the Penn Yan-Hammondsport Quadrangles. $28 \mathrm{p}$. map. July I906. Out of print.

I 4 Hartnagel, C. A. Geologic Map of the Rochester and Ontario Beach Quadrangles. 36p. map. Aug. I907. $20 \mathrm{c}$.

I 8 Clarke, J. M. \& Luther, D. D. Geologic Maps and Descriptions of the Portage and Nunda Quadrangles including a map of Letchworth Park. 5op. I6pl. 4 maps. Jan. I908. 35c.

328 Luther, D. D. Geology of the Geneva-Ovid Quadrangles. 44p. map. Apr. I909. $20 \mathrm{c}$.

Geology of the Phelps Quadrangle. In preparation.

Whitnall, H. O. Geology of the Morrisville Quadrangle. Prepared. 
Hopkins, T. C. Geology of the Syracuse Quadrangle. Prepared.

Hudson, G. H. Geology of Valcour Island. In preparation.

Zoology. I Marshall, W. B. Preliminary List of New York Unionidae. 20p. Mar. 1892 . Free.

9 Beaks of Unionidae Inhabiting the Vicinity of Albany, N. Y. 30 p. I pl. Aug. I890. Free.

29 Miller, G. S. jr. Preliminary List of New York Mammals. I 24p. Oct. I 899 . I 5 C.

33 Farr, M. S. Check List of New York Birds. 224p. Apr. 1900. $25 \mathrm{c}$.

38 Miller, G. S. jr. Key to the Land Mammals of Northeastern North America. Io6p. Oct. I900. I5c.

40 Simpson, G. B. Anatomy and Physiology of Polygyra albolabris and Limax maximus and Embryology of Limax maximus. $82 \mathrm{p} .28 \mathrm{pl}$. Oct. I $90 \mathrm{I} .25 \mathrm{C}$.

43 Kellogg, J. L. Clam and Scallop Industries of New York. 36p. $2 \mathrm{pl}$. map. Apr. r 901 . Free.

5 I Eckel, E. C. \& Paulmier, F. C. Catalogue of Reptiles and Batrachians of New York. 64p. il. Ipl. Apr. rgo2. Out of print.

Eckel, E. C. Serpents of Northeastern United States.

Paulmier, F. C. Lizards, Tortoises and Batrachians of New York.

6o Bean, T. H. Catalogue of the Fishes of New York. 784p. Feb. I903. $\$ 1$, cloth.

7 I Kellogg, J. L. Feeding Habits and Growth of Venus mercenaria. 30p. 4pl. Sept. 1903. Free.

88 Letson, Elizabeth J. Check List of the Mollusca of New York. I I6p. May $1905.20 \mathrm{c}$.

91 Paulmier, F. C. Higher Crustacea of New York City. 78p. il. June $1905.20 \mathrm{C}$.

130 Shufeldt, R. W. Osteology of Birds. 382p. il. $26 \mathrm{pl}$. May rgog. $50 \mathrm{c}$. Entomology. 5 Lintner, J. A. White Grub of the May Beetle. 34p. il. Nov. I 888 . Free.

6 - Cut-worms. 38p. il. Nov, 1888. Free.

13 - San José Scale and Some Destructive Insects of New York State. 54p. 7pl. Apr. I 895. I 5 C.

20 Feit, E. P. Elm Leaf Beetle in New York State. 46p. il. 5 pl. June I 898 . Free.

See 57 .

23 I4th Report of the State Entomologist r898. I50p. il. 9pl. Dec. I 898 . 20c.

24 Memorial of the Life and Entomologic Work of I. A. Lintner Ph.D. State Entomologist 1874-98; Index to Entomologist's Reports I-13. 3 I6p. rpl. Oct. 1899 . 35 c.

Supplement to I 4 th report of the State Entomologist.

26 - Collection, Preservation and Distribution of New York Insects. 36p. il. Apr. 1899. Free.

27 Shade Tree Pests in New York State. 26p. il. 5pl. May 1899. Free.

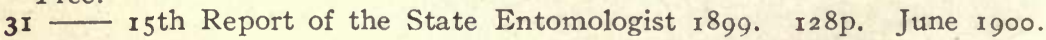

36 I 5 . 16 th Report of the State Entomologist r9oo. Ix 8 p. I6pl. Mar. I $90 \mathrm{I} .25 \mathrm{C}$.

37 Catalogue of Some of the More Important Injurious and Beneficial Insects of New York State. 54p. il. Sept. I900. Free.

46 - Scale Insects of Importance and a List of the Species in New York State. 94p. il. r $5 \mathrm{pl}$. June rgor. 25c.

47 Needham, J. G. \& Betten; Cornelius. Aquatic Insects in the Adirondacks. 234p. il. $36 \mathrm{pl}$. Sept. I901. 45c.

53 Felt, E. P. I 7 th Report of the State Entomologist r 90 r. 232p. il. 6 pl. Aug. 1902. Out of print. 
57-_ Elm Leaf Beetle in New York State. 46p. il. 8pl. Aug. rgo2. Out of print.

This is a revision of Bulletin 20 containing the more essential facts observed since that was prepared.

59 - Grapevine Root Worm. 40p. 6pl. Dec. I902. I5c.

See 72 .

64 - I8th Report of the State Entomologist rgo2. r rop. 6pl. May I $903.20 \mathrm{C}$.

68 Needham, J. G. \& others. Aquatic Insects in New York. 322p. 52 pl. Aug. I 903 . 80c, cloth.

72 Felt, E. P. Grapevine Root Worm. 58p. r3pl. Nov. rgo3. . 2oc.

This is a revision of Bulletin 59 containing the more essential facts observed since that was prepared.

74 \& Joutel, L. H. Monograph of the Genus Saperda. 88p. r4pl. June I $904.25 \mathrm{c}$.

76 Felt, E. P. r rth Report of the State Entomologist 1903. I50p. $4 \mathrm{pl}$. I 904 . I $5 \mathrm{C}$.

79 Mosquitos or Culicidae of New York. 164p. il. 57pl. tab. Oct. I $904.40 \mathrm{c}$.

86 Needham, J. G. E others. May Flies and Midges of New York. $35^{2} \mathrm{p}$. il. $37 \mathrm{pl}$. June I905. 80c, cloth.

97 Felt, E. P. 2oth Report of the State Entomologist I904. 246p. il. I9pl. Nov. I905. $40 \mathrm{c}$.

I03 - Gipsy and Brown Tail Moths. 44p. Iopl. July r go6. I 5 c.

ro4 - 2 Ist Report of the State Entomologist r905. I44p. ropl. Aug. I $906.25 \mathrm{c}$.

rog - Tussock Moth and Elm Leaf Beetle. 34p. 8pl. Mar. 1907. $20 \mathrm{c}$. I IO - $22 \mathrm{~d}$ Report of the State Entomologist igo6. I52p. $3 \mathrm{pl}$. June I $907.25 \mathrm{C}$.

I 24 23 d Report of the State Entomologist r 907 . 542p. il. 44pl. Oct. I $908.75 \mathrm{C}$.

I 29 - Control of Household Insects. 48p. il. May rgog. Out of print.

r34 - 24th Report of the State Entomologist I908. 208p. il. I7pl. Sept. I $909.35 \mathrm{c}$.

136 Control of Flies and Other Household Insects. 56p. il. Feb. I9I0. I5C.

This is a revision of Bulletin $\mathbf{r} 29$ containing the more essential facts observed sinc that was prepared.

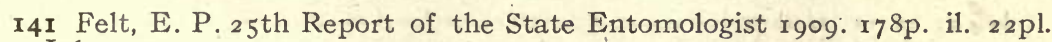
July i 9 io. $35 \mathrm{c}$.

147 - 26 th Report of the State Entomologist rgro. I82p. il. 35pl. Mar. I9II. $35 \mathrm{C}$.

Needham, J. G. Monograph on Stone Flies. In preparation.

Botany. 2 Peck, C. H. Contributions to the Botany of the State of New York. $72 \mathrm{p} .2 \mathrm{pl}$. May $\mathrm{r} 887$. Out of print.

8 - Boleti of the United States. $98 \mathrm{p}$. Sept. r 889 . Out of print.

$25-$ Report of the State Botanist 1898 . 76p. $5 \mathrm{pl}$. Oct. r 899 . Out of print.

28 Plants of North Elba. 206p. map. June r 899. 20c.

54 - Report of the State Botanist r ror. 58p. 7pl. Nov. 1902. $40 \mathrm{c}$.

67 - Report of the State Botanist 1902. 196p. 5pl. May 1903. $50 \mathrm{c}$.

75 - Report of the State Botanist r903. 70p. 4pl. 1904. 40c.

94 - Report of the State Botanist r 904 . 6op. ropl. July I905. $40 \mathrm{c}$.

ro5 - Report of the State Botanist r905. ro8p. r2pl. Aug. rgo6. 50c.

II6 - Report of the State Botanist rgo6. I20p. 6pl. July igo7. 35c.

122 - Report of the State Botanist I907. I 78p. 5pl. Aug. I908. 40c.

I3I - Report of the State Botanist r908. 202p. 4pl. July r909. $40 \mathrm{c}$.

r 39 - Report of the State Botanist rgog. Ir6p. ropl. May rgro. $45 \mathrm{c}$.

I50 - Report of the State Botanist I9ro. Ioop. 5pl. May I9ri. 30c.

Archeology. I6 Beauchamp, W. M. Aboriginal Chipped Stone Implements of New York. 86p. 23 pl. Oct. 1897. 25c.

I 8 Polished Stone Articles Used by the New York Aborigines. roup. 3.5pl. Nov, I $897.25 \mathrm{c}$. 
22 - Earthenware of the New York Aborigines. 78 p. 33pl. Oct. 1898. $25 \mathrm{C}$.

32 - Aboriginal Occupation of New York. I90p. I6pl. 2 maps. Mar. I 900 . 30c.

4I 1 Wampum and Shell Articles Used by New York Indians. I66p. 28pl. Mar. I901. 30c.

50 Horn and Bone Implements of the New York Indians. I I 2p. $43 \mathrm{pl}$. Mar. I $902.30 \mathrm{c}$.

55 Metallic Implements of the New York Indians. 94p. $3^{8 \mathrm{p}}$. June 1902. $25 \mathrm{c}$.

73 Metallic Ornaments of the New York Indians. 122p. $37 \mathrm{pl}$. Dec.

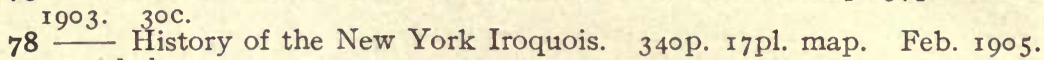
$75 \mathrm{c}$, cloth.

87 Perch Lake Mounds. 84p. r2pl. Apr. 1905. Out of print.

89 - Aboriginal Use of Wood in New York. I90p. 35pl. June I905. $35 \mathrm{c}$.

ro8 - Aboriginal Place Names of New York. 336p. May r9o7. $40 \mathrm{c}$.

Ir3 - Civil, Religious and Mourning Councils and Ceremonies of Adoption. Ir 8p. $7 \mathrm{pl}$. June $1907.25 \mathrm{C}$.

I17 Parker, A. C. An Erie Indian Village and Burial Site. ro2p. $38 \mathrm{pl}$. Dec. 1907 . 30c.

125 Converse, H. M. \& Parker, A. C. Iroquois Myths and Legends. I96p. il. I I pl. Dec. I 908 . 50c.

144 Parker, A. C. Iroquois Uses of Maize and Otlier Food Plants. I 20 p. il. 3 I pl. Nov. I9ro. 30c.

Miscellaneous. Ms I (62) Merrill, F. J. H. Directory of Natural History Museums in United States and Canada. 236p. Apr. 1903. 30c.

66 Ellis, Mary. Index to Publications of the New York State Natural History Survey and New York State Museum 1837-1902. 418p. June r 903 . $75 \mathrm{c}$, cloth.

Museum memoirs r889-date. 4to.

I Beecher, C. E. \& Clarke, J. M. Development of Some Silurian Brachiopoda. $96 \mathrm{p} .8 \mathrm{pl}$. Oct. r 889 . \$r.

2 Hall, James \& Clarke, J. M. Paleozoic Reticulate Sponges. 350p. il. $70 \mathrm{pl}$ I 898 . \$2, cloth.

3 Clarke, J. M. The Oriskany Fauna of Becraft Mountain, Columbia Co., N. Y. I28p. 9pl. Oct. I900. 80c.

4 Peck, C. H. N. Y. Edible Fungi, I895-99. ro6p. 2 5pl. Nov. I900. [\$1.25]

This includes revised descriptions and illustrations of fungi reported in the 49 th, 51 st and $52 \mathrm{~d}$ reports of the State Botanist.

5 Clarke, J. M. \& Ruedemann, Rudolf. Guelph Formation and Fauna of New York State. r96p. 2 I pl. July r 903 \$r.5o, cloth.

6 Clarke, J. M. Naples Fauna in Western New York. 268p. 26pl. map. 1904. \$2, cloth.

7 Ruedemann, Rudolf. Graptolites of New York. Pt I Graptolites of the Lower Beds. 350p. I 7pl. Feb. I905. \$1.50, cloth.

8 Felt, E. P. Insects Affecting Park and Woodland Trees. v.r. 46op. il. 48 pl. Feb. I906. \$2.50, cloth; v. 2. 548p. il. 22 pl. Feb. 190\%. \$2, cloth.

9 Clarke, J. M. Early Devonic of New York and Eastern North America. Pt I. 366 p. il. 70pl. 5 maps. Mar. 1908. \$2.50, cloth; Pt 2.250p. il. 36 pl. 4 maps. Sept. I 909 . \$2, cloth.

ro Eastman, C. R. The Devonic Fishes of the New York Formations. $236 \mathrm{p}$. I 5 pl. I 907 . \$1.25, cloth.

I I Ruedemann, Rudolf. Graptolites of New York. Pt 2 Graptolites of the Higher Beds. 584 p. il. 3 I pl. 2 tab. Apr. I908. $\$ 2.50$, cloth.

12 Eaton, E. H. Birds of New York. v. I. 5oip. il. $42 \mathrm{pl}$. Apr. I9ro. $\$ 3$, cloth; v, 2, in press.

r3 Whitlock, H.P. Calcites of New York. Igop. il. 27 pl. Oct. rgro. \$r, cloth. Clarke, J. M. \& Ruedemann, Rudolf. The Eurypterida of New York, In press. 


\section{MUSEUM PUBLICATIONS}

Natural history of New York. 30v. il. pl. maps. 4to. Albany r 842-94. Division r Zoology. De Kay, James E, Zoology of New York; or, The New York Fauna; comprising detailed descriptions of all the animals hitherto observed within the State of New York with brief notices of those occasionally found near its borders, and accompanied by appropriate illustrations. 5v. il. pl. maps. sq. 4to. Albany 1842-44. Out of print.

Historical introduction to the series by Gov. W. H. Seward. $178 \mathrm{p}$.

V. I ptr Mammalia. I3I + 46p. 33pl. I842.

300 copies with hand-colored plates.

v. 2 pt 2 Birds. I $2+380$ p. I 4 rpl. I 844 .

Colored plates.

v. $3 \mathrm{pt}_{3}$ Reptiles and Amphibia. $\quad 7+98 \mathrm{p}$. pt 4 Fishes. $\quad$ I5 +4 i $5 p . \quad$ I 842 . pt 3-4 bound together.

v. 4 Plates to accompany v. 3. Reptiles and Amphibia. 23pl. Fishes. 79pl. 1842 .

300 copies with hand-colored plates.

v. 5 pt5 Mollusca. $4+27$ rp. 40pl. pt 6 Crustacea. 70p. I3pl. I843-44. Hand-colored plates; pt5-6 bound together.

DIvision 2 Botany. Torrey, John. Flora of the State of New York; comprising full descriptions of all the indigenous and naturalized plants hitherto discovered in the State, with remarks on their economical and medical properties. 2v. il. pl. sq. 4to. Albany i 843 . Out of print.

v. I Flora of the State of New York. I $2+484 \mathrm{p} .72 \mathrm{pl}$. I 843 .

300 copies with hand-colored plates.

v. 2 Flora of the State of New York. 572 p. $89 \mathrm{pl}$. $\quad$ I 843 .

300 copies with hand-colored plates.

Division 3 Mineralogy. Beck, Lewis C. Mineralogy of New York; comprising detailed descriptions of the minerals hitherto found in the State of New York, and notices of their uses in the arts and agriculture. il. pl. sq. 4to. Albany r842. Out of print.

v. I ptr Economical Mineralogy. pt2 Descriptive Mineralogy. $24+536$ p. I 842 .

8 plates additional to those printed as part of the text.

DIVISION 4 GEOLOGY. Mather, W. W.; Emmons, Ebenezer; Vanuxem, Lardner \& Hall, James. Geology of New York. 4v. il. pl. sq. 4to. Albany I842-43. Out of print.

v. I pt I Mather, W. W. First Geological District. $37+653 \mathrm{p} .46 \mathrm{pl}$. I 843.

v. 2 pt2 Emmons, Ebenezer. Second Geological District. Io $+437 \mathrm{p}$. I 7 pl. I 842 .

v. $3 \mathrm{pt}_{3}$ Vanuxem, Lardner. Third Geological District. $306 \mathrm{p}$. 1842.

v. 4 pt4 Hall, James. Fourth Geological District. $22+683$ p. Igpl. map. r 843 .

Division 5 agriculture. Emmons, Ebenezer. Agriculture of New York; comprising an account of the classification, composition and distribution of the soils and rocks and the natural waters of the different geological formations, together with a condensed view of the meteorology and agricultural productions of the State. 5v. il. pl. sq. 4to. Albany 1846-54. Out of print.

v. I Soils of the State, their Composition and Distribution. I I +37 Ip. 2 I pl. I 846 .

v. a Analysis of Soils, Plants, Cereals, etc. $8+343+46$ p. $\quad 42$ pl. $\quad$ I 849 .

With hand-colored plates. 
v. 3 Fruits, etc. $8+340$ p. 185 I.

v. 4 Plates to accompany v. 3. 95pl. I85I.

Hand-colored.

v. 5 Insects Injurious to Agriculture. $8+272 \mathrm{p}$. 50pl. I854.

With hand-colored plates.

division 6 paleontology. Hall, James. Palaeontology of New York. 8v. il. pl. sq. 4to. Albany 1847-94. Bound in cloth.

v. I Organic Remains of the Lower Division of the New York System. $23+338$ p. 99pl. I 847. Out of print.

v. 2 Organic Remains of Lower Middle Division of the New York System. $8+362$. 104pl. I 852 . Out of print.

v. 3 Organic Remains of the Lower Helderberg Group and the Oriskany Sandstone. pt 1 , text. $12+532 \mathrm{p}$. I 859 . [\$3.50]

- pt 2. r $43 \mathrm{pl}$. I 86 I. [\$2.50]

v. 4 Fossil Brachiopoda of the Upper Helderberg, Hamilton, Portage and Chemung Groups. I I + I $+428 \mathrm{p} .69 \mathrm{pl}$. I867. \$2.50.

v. $5 \mathrm{pt}$ I Lamellibranchiata I. Monomyaria of the Upper Helderbergs, Hamilton and Chemung Groups. $18+268 \mathrm{p} .45 \mathrm{pl}$. I884. \$2.50.

- Lamellibranchiata 2. Dimyaria of the Upper Helderberg, Hamilton, Portage and Chemung Groups. $62+293 p$. 5 I pl. I885. \$2.50. - pt 2 Gasteropoda, Pteropoda and Cephalopoda of the Upper Helderberg, Hamilton, Portage and Chemung Groups. 2v. I879. v. r, text. I $5+492$ p.; v.2. I 20pl. $\$ 2.50$ for $2 \mathrm{~V}$.

\& Simpson, George B. v. 6 Corals and Bryozoa of the Lower and Upper Helderberg and Hamilton Groups. $24+298 \mathrm{p} .67 \mathrm{pl}$. 1887. \$2.50. \& Clarke, John M. v. 7 Trilobites and other Crustacea of the Oriskany, Upper Helderberg, Hamilton, Portage, Chemung and Catskill Groups. $64+236 \mathrm{p} .46 \mathrm{pl}$. I888. Cont. supplement to v. 5, pt 2. Pteropoda, Cephalopoda and Annelida. 42p. I8pl. I888. \$2.50.

- \& Clarke, John M. v. 8 pt I Introduction to the Study of the Genera of the Paleozoic Brachiopoda. I6 + 367p. $44 \mathrm{pl}$. I 892 . $\$ 2.50$.

\& Clarke, John M. v. 8 pt 2 Paleozoic Brachiopoda. I6 + 394p. 64pl, I894. $\$ 2.50$.

Catalogue of the Cabinet of Natural History of the State of New York and of the Historical and Antiquarian Collection annexed thereto. 242p. 8 vo. I 853 .

Handbooks r893-date.

In quantities, I cent for each 16 pages or less. Single copies postpaid as below.

New York State Museum. 52p. il. Free.

Outlines, history and work of the museum with list of staff 1902.

Paleontology. I2p. Free.

Brief outline of State Museum work in paleontology under heads: Definition; Relation to biology; Relation to stratigraphy; History of paleontology in New York.

Guide to Excursions in the Fossiliferous Rocks of New York. 124p. Free.

Itineraries of 32 trips covering nearly the entire series of Paleozoic rocks, prepared specially for the use of teachers and students desiring to acquaint themselves more intimately with the classic rocks of this State.

Entomology. 16p. Free.

Economic Geology. 44p. Free.

Insecticides and Fungicides. 20p. Free.

Classification of New York Series of Geologic Formations. 32p. Free.

Geologic maps. Merrill, F. J. H. Economic and Geologic Map of the State of New York; issued as part of Museum bulletin I 5 and 48 th Museum report, v. I. $59 \times 67 \mathrm{~cm}$. I 894 . Scale I 4 miles to I inch. I $5 \mathrm{c}$. 
Map of the State of New York Showing the Location of Quarries of Stone Used for Building and Road Metal. Mus. Bul. r 7. r897. Free. Map of the State of New York Showing the Distribution of the Rocks Most Useful for Road Metal. Mus. Bul. 17. 1897. Free.

Geologic Map of New York. Igor. Scale 5 miles to I inch. In atlas form $\$ 3 ;$ mounted on rollers $\$ 5$. Lower Hudson sheet $60 c$.

The lower Hudson sheet, geologically colored, comprises Rockland, Orange, Dutchess, Putnam, Westchester, New York, Richmond, Kings, Queens and Nassau counties, and parts of Sullivan, Ulster and Suffolk counties; also northeastern New Jersey and part of western Connecticut.

Map of New York Showing the Surface Configuration and Water Sheds. rgor. Scale I 2 miles to I inch. I $5 \mathrm{c}$.

Map of the State of New York Showing the Location of its Economic Deposits. I904. Scale I 2 miles to I inch. I5 C.

Geologic maps on the United States Geological Survey topographic base. Scale $\mathrm{r}$ in. $=\mathrm{I}$. Those marked with an asterisk have also been pub. lished separately.

*Albany county. Mus. Rep't 49, v. 2. I898. Out of print.

Area around Lake Placid. Mus. Bul. 2 r. I898.

Vicinity of Frankfort Hill [parts of Herkimer and Oneida counties]. Mus. Rep't 5r, v. I. 1899.

Rockland county. State Geol. Rep't I8. $\quad$ 1899.

Amsterdam quadrangle. Mus. Bul. 34. rgoo.

* Parts of Albany and Rensselaer counties. Mus. Bul. 42. Iyor. Free.

* Niagara river. Mus. Bul. 45. I90 I. $25 \mathrm{c}$.

Part of Clinton county. State Geol. Rep't r9. I90r.

Oyster Bay and Hempstead quadrangles on Long Island. Mus. Bul. $4^{8}$. I90I.

Portions of. Clinton and Essex counties. Mus. Bul. 52. rgo2.

Part of town of Northumberland, Saratoga co. State Geol. Rep't 2 I. 1903.

Union Springs, Cayuga county and vicinity. Mus. Bul. 69. I903.

* Olean quadrangle. Mus. Bul. 69. 1903. Free.

*Becraft Mt with 2 sheets of sections. (Scale $\mathrm{r}$ in. $=\frac{1}{2} \mathrm{~m}$.) Mus. Bul. 69. I $903.20 \mathrm{C}$.

*Canandaigua-Naples quadrangles. Mus. Bul. 63. I904. $20 \mathrm{c}$.

*Little Falls quadrangle. Mus. Bul. 77. 1905. Free.

*Watkins-Elmira quadrangles. Mus. Bul. 8I. I905. $20 \mathrm{c}$.

*Tully quadrangle. Mus. Bul. 82. rgo5. Free.

* Salamanca quadrangle. Mus. Bul. 80. rgo5. Free.

* Mooers quadrangle. Mus. Bul. 83. I905. Free.

*Buffalo quadrangle. Mus. Bul. 99. I 906 . Free.

*Penn Yan-Hammondsport quadrangles. Mus. Bul. ror. I906. 20c.

* Rochester and Ontario Beach quadrangles. Mus. Bul. ir $4.20 c$.

* Long Lake quadrangle. Mus. Bul. ir 5 . Free.

*Nunda-Portage quadrangles. Mus. Bul. I $8.20 c$.

*Remsen quadrangle. Mus. Bul. 126. r908. Free.

*Geneva-Ovid quadrangles. Mus. Bul. I28. I909. $20 c$.

* Port Leyden quadrangle. Mus Bul. I35. r9 10. Free.

* Auburn-Genoa quadrangles. Mus. Bul. I37. I9 1o. $20 \mathrm{c}$.

* Elizabethtown and Port Henry quadrangles. Mus. Bul. r38. rgro. r5c. * Alexandria Bay quadrangle. Mus. Bul. I45. Free.

* Cape Vincent quadrangle. Mus. Bul. r45. Free.

* Clayton quadrangle. Mus. Bu1. I45. Free.

*Grindstone quadrangle. Mus. Bul. I 45. Free.

*Theresa quadrangle. Mus. Bul. I45. Free.

* Poughkeepsie quadrangle, Mus. Bul, i 48 . Free.

${ }^{*}$ Honeoye-Wayland quadrangle. Mus. Bul. 152. $20 c$. 


$x^{3}+x^{2}$

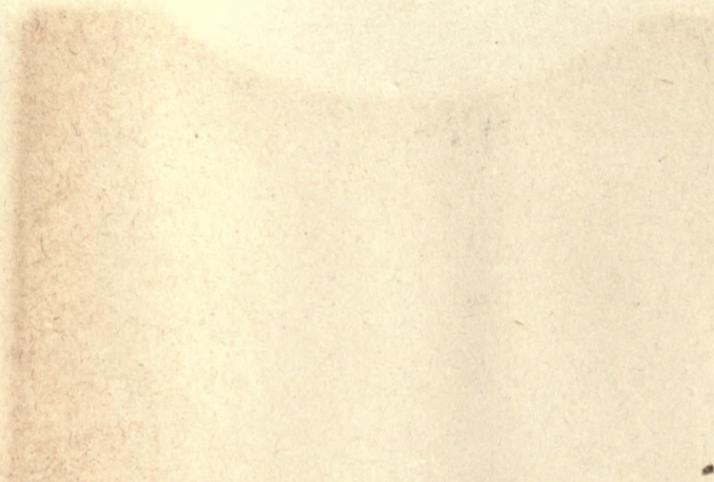

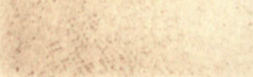


New York state 333205

miserum bul tet

Museum bulletin.
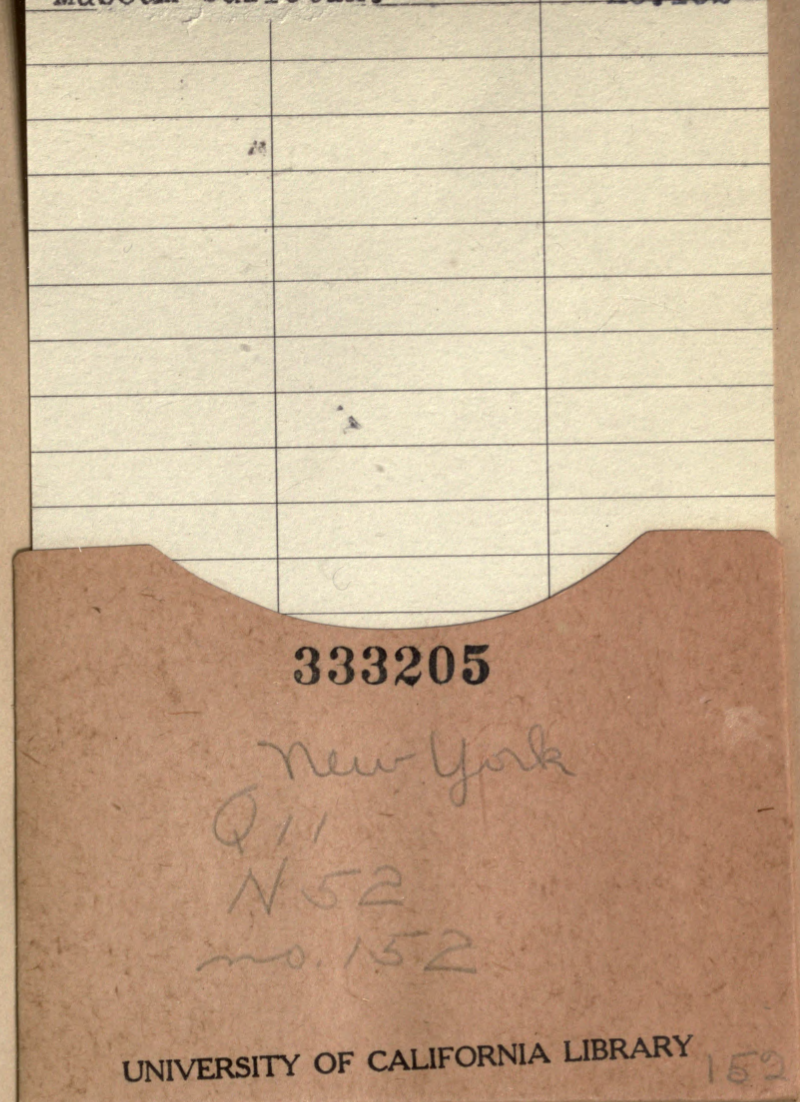

욜 
